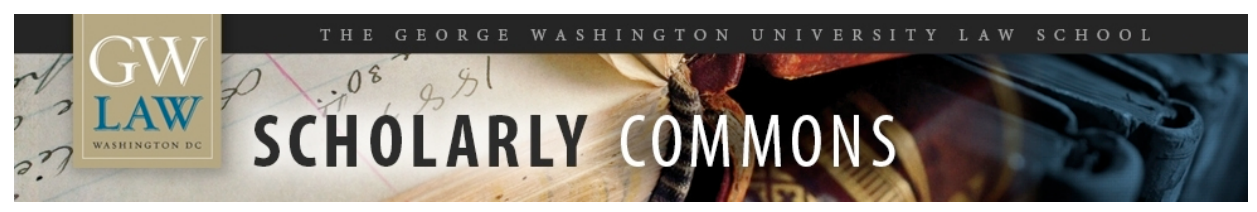

\title{
Hobby Lobby and the Dubious Enterprise of Religious Exemptions
}

Ira C. Lupu

George Washington University Law School

Follow this and additional works at: https://scholarship.law.gwu.edu/faculty_publications

Part of the Law Commons

\section{Recommended Citation}

38 Harv. J.L. \& Gender (forthcoming 2015)

This Article is brought to you for free and open access by the Faculty Scholarship at Scholarly Commons. It has been accepted for inclusion in GW Law Faculty Publications \& Other Works by an authorized administrator of Scholarly Commons. For more information, please contact spagel@law.gwu.edu. 
Hobby Lobby and the Dubious Enterprise of Religious Exemptions

Harvard Journal of Law \& Gender, Vol. 38, \#1 (forthcoming, 2015, in Symposium, Religious Accommodation in the Age of Civil Rights)

Ira C. Lupu ${ }^{1}$

The experience of the past fifty years, culminating in Burwell v. Hobby Lobby Stores, Inc., is grounds for deep skepticism of any sweeping regime of religious exemptions. Part I of this essay locates the problem in the current legal and cultural moment, which includes religious objections to employer-provided contraceptive care for women, and religion-based refusals by wedding vendors and others to facilitate the celebration of same sex marriages. Part II broadens the time frame to analyze the regimes of religious exemption -federal and state, constitutional and statutory -- in which such disputes play out. Such regimes will tend to be rhetorically strong and experientially weak, with an occasional outburst of religion-protecting vigor. Burwell v. Hobby Lobby, analyzed in Part III, demonstrates yet again that application of vague, general standards for adjudicating religious exemption claims cannot satisfy values associated with the rule of law. The key terms in the Religious Freedom Restoration Act are perpetually contested and subject to infinite, result-oriented manipulability. Part $I V$ concludes with a prediction that Burwell v. Hobby Lobby will suffer the same fate as earlier, apparently strenuous embraces of religious exemptions. Ultimately, it will wither on a malnourished vine.

\section{INTRODUCTION}

Everyone has intuitions about exempting religious objectors from legal duties with which others must comply. Almost no one thinks that American law would be truly and adequately respectful of religious freedom if the law offered no avenue to accommodate deeply held, conscientious religious commitments. Moreover, almost no one thinks that legislatures or administrators can be fully trusted to produce an optimum mix of well-deserved, practice-specific accommodations -- that is, to do justice over time in the mix of grants and denials

\footnotetext{
${ }^{1}$ F. Elwood \& Eleanor Davis Professor of Law Emeritus, George Washington University. My thanks to the organizers of the Symposium on Religious Accommodations in the Age of Civil Rights for the invitation to submit a paper for the published version; to Bob Tuttle for very helpful comments on an earlier draft of the piece; and to Christina Hobbs, a member of the class of 2016 at George Washington University, whose research assistance contributed significantly. The errors are mine.
} 
of such accommodations. Power advantage, manipulation and control of agendasetting, and religious prejudice are likely to be all too prominent in the legislative process, and frequently in administrative processes as well.

With this set of intuitions, the choice to involve an impartial judiciary, obliged to hear claims of all, in the enterprise of religious accommodation seems to be salutary. Case by case adjudication, under general standards, guided by reliance on precedent and analogical reasoning, appears to offer hope for a just process of determining when religiously motivated practices should be shielded from negative legal consequences.

That ease of first glance extends to substance as well as to process. When confronted with examples, most people can identify religious claims that appear highly exemption-worthy, because denying them appears to greatly intrude on faith while producing little or no public benefit. Consider the example of a school that forbids the wearing of hats, and its consequent refusal to accommodate a child whose faith requires him or her to wear a head covering. And everyone can identify claims that seem obviously NOT exemption-worthy, because granting them appears to produce a risk of significant harm to others. Consider the example of an airline passenger who asserts that her faith requires her to carry a deadly weapon at all times.

Having constructed categories of easy cases, defined primarily (though not exclusively) by risk of harm, everyone will eventually arrive at close or difficult cases with respect to granting accommodations or exemptions. Perhaps we are unsure of the significance of certain practices within a particular faith; perhaps the risk of harm they create is in a non-trivial mid-range. Consider the example of a soldier who asserts that she can never work the evening shift on a military base because, she claims, she has religious duties at home during the evening hours. Her religious duties may be difficult for outsiders to her faith to understand, and accommodating her faith commitments inevitably will impose extra evening work on others.

In these kinds of cases, judges typically will want to know more about the religious practice, its significance to its adherents, and the harms to others that may follow from accommodating the practice. As information thickens, and the number of variations proliferates, judges will soon be forced to confront a set of 
conflicting intuitions, not only about the cases in the middle ground, but also about which cases fall into each of three categories - yes, no, maybe. They will be uncertain about so many of the relevant variables - the faith, the role of the practice within it, the religious significance of accommodation or nonaccommodation, and the costs that accommodation may inflict on government interests or private third parties. At a level deeper, judges may also be concerned about the sincerity of exemption claimants, the incentives that a proexemption ruling may create for insincere claims, the intrusiveness of the process for weeding out insincere claims, and so on. Alas, judges will find no satisfactory template in existing or past law for rigorous and principled evaluation of these multiple variables. Eventually, as cases accumulate, we will be left with a pattern of results that cannot be defended as a whole.

Adjudication of religious exemptions, under any set of general criteria, repeatedly reveals this dilemma. We can opt for a judicially administered, generalized exemption regime that will in particular cases result in what some observers will see as "good outcomes," all-things considered. Over time, however, that regime is highly likely to be unprincipled, ad hoc, inconsistent, subject to manipulation, and frequently biased for or against certain faiths. Moreover, to the extent the regime permits judges to determine the religious weight and significance of certain practices, the regime unconstitutionally entrusts the state with questions that it is constitutionally incompetent to answer. ${ }^{2}$ In order to avoid those problems, which involve serious concerns of justice and constitutional limitation, we can opt to eliminate any such regime of adjudication. That would limit religion-specific exemptions of particular practices to those produced by legislation and administration, subject to Establishment Clause limitation. ${ }^{3}$ In practice, no other systemic choice exists.

\footnotetext{
${ }^{2}$ See generally Ira C. Lupu \& Robert W. Tuttle, Secular Government, Religious People 226-232(Wm. B. Eerdmans Pub. Co., 2014) (hereafter, "Lupu \& Tuttle"); Ira C. Lupu \& Robert W. Tuttle, The Forms and Limits of Accommodation: The Case of RLUIPA, 32 Cardozo L. Rev. 1907 (2011).

${ }^{3}$ Those limitations tend to be under-noticed and highly significant. For an excellent elaboration of the Establishment Clause limitations on discretionary religious accommodations, see Frederick Gedicks and Rebecca Van Trammel, RFRA Exemptions from the Contraception Mandate: An Unconstitutional Accommodation of Religion, 49 Harv. Civ. Rts. Civ. L. Rev. _ (forthcoming, Summer 2014); Lupu \& Tuttle, supra note 2, at 216-225.
} 
My approach to this set of issues is Holmesian, grounded in experience rather than abstract logic. ${ }^{4}$ Part I locates the piece in the moment - that is, in our current situation of conflict over religious accommodations with respect to 1 ) the Affordable Care Act's requirement of contraceptive coverage in health insurance, and 2) legal duties to refrain from discrimination on the basis of sexual orientation. Part II turns to the historical evidence that a generalized exemption regime will be rhetorically strong, experientially weak, and relentlessly ad hoc in its results. Part II.A. addresses the experience from 1963-1990 under a constitutional regime of free exercise exemptions. Part II.B. analyzes the record of adjudication under federal RFRA, both before and after City of Boerne $v$. Archbishop Flores $^{5}$ (1997), which invalidated RFRA as applied to the states. Part II.C. compares the experience under state RFRA's in the same twenty-plus year period. Part III then analyzes the Contraceptive Mandate Cases in light of the general regime concerns that this history illustrates, and shows how the various opinions in those cases perfectly illustrate the general dilemma of adjudicating religious exemptions under a set of general standards. Part III concludes with an assessment, drawn from this experience over half a century, of the implications of the Contraceptive Mandate Cases for future conflict between religious freedom and marriage equality.

\section{Culture Wars and Religious Accommodations}

Through the late winter and spring of 2014, lawyers and scholars focused on religious liberty watched with mounting engagement and anxiety as a number of parallel battles played out. The most prominent one, which had roiled American law and politics over the prior few years, involved the Affordable Care Act's requirement that employer-provided health insurance include all forms of female contraception. The Supreme Court's decision in Burwell v. Hobby Lobby

\footnotetext{
${ }^{4}$ Holmes, Oliver Wendell, Jr. The Common Law (1881) (Little, Brown, \& Co.): "The life of the law has not been logic; it has been experience." To be sure, there have been powerful voices behind the view that a regime of free exercise exemptions is normatively indefensible. See, e.g., Christopher L. Eisgruber \& Lawrence G. Sager, Religious Freedom and the Constitution (Harv. U. Press 2007) at 78-120; Frederick Mark Gedicks, An Unfirm Foundation: The Regrettable Indefensibility of Religious Exemptions, 20 U. Ark. Little Rock L.J. 555 (1998); William P. Marshall, William P. Marshall, In Defense of Smith and Free Exercise Revisionism, 58 U. Chi. L. Rev. 308 (1991). I remain normatively agnostic about such exemptions. My argument is that they have proven to be institutionally impossible. For a very different approach, leading to a similar conclusion, see Winnifred Fallers Sullivan, The Impossibility of Religious Freedom (Princeton U. Press, 2007).

${ }^{5} 521$ U.S. 507 (1997).
} 
Stores, Inc. ${ }^{6}$ (hereafter "Hobby Lobby") has now resolved several aspects of those disputes. But, as discussed in Part III, the decision leaves open a number of crucial questions, including most urgently the question of the legal validity of the existing accommodation for religiously affiliated non-profit institutions. ${ }^{7}$

Despite understandable public expectations to the contrary, the most important legal authority in the cases concerning the contraceptive mandate has never been the Free Exercise Clause of the First Amendment. No court has ever found that the mandate violates the Free Exercise Clause. Instead, the Religious Freedom Restoration Act ${ }^{8}$ of 1993 (hereafter "RFRA" or "federal RFRA") has been the center of legal gravity for this body of litigation. But the dominance of RFRA has meant all along that the Supreme Court's interpretation of the Free Exercise Clause, in an earlier era, has haunted the scene.

Here is the brief, operative provision of federal RFRA: ${ }^{9}$

(a) In general

Government shall not substantially burden a person's exercise of religion even if the burden results from a rule of general applicability, except as provided in subsection (b) of this section.

(b) Exception

Government may substantially burden a person's exercise of religion only if it demonstrates that application of the burden to the person-

(1) is in furtherance of a compelling governmental interest; and

(2) is the least restrictive means of furthering that compelling governmental interest.

RFRA's general prohibition on government burdening religious exercise appears to be a strict command ("shall not"); RFRA's exception looks familiar to

6573 U.S. _ (2014); 2014 U.S. LEXIS 450582 (No. 13-354, June 30, 2014) (decided together with Conestoga Wood Specialties Corp. v. Sebelius, No, 13-356).

7 Compare Univ. of Notre Dame v. Sebelius, 743 F. 3d 547 (7th Cir. 2014) with Little Sisters of the Poor Home for the Aged v. Sebelius, 134 S. Ct. 1022 (2014), rev'g, No. 13-cv-2611-WJM-BNB, 2013 WL 6839900 (D. Colo. Dec. 27, 2013). See also Wheaton College v. Burwell, http://www.supremecourt.gov/opinions/13pdf/13a1284_ap6c.pdf. There also remains the question of the application of the Hobby Lobby decision to for-profit firms that object to covering all female contraceptives, not only those considered by the employer to be abortifacients. See the Supreme Court's orders to the Circuit Courts to reconsider cases, linked and summarized here: http://www.scotusblog.com/2014/07/wider-impact-of-hobbylobby-ruling/, involving RFRA challenges to coverage of all pregnancy prevention services. No one expects those decisions to be resolved against the objecting firms.

842 U.S.C. secs. 2000 bb et seq.

${ }^{9} 42$ U.S.C. sec. $2000 \mathrm{bb}-1$. 
constitutional lawyers, well-acquainted with the language of compelling interests and least restrictive means, both of which ordinarily signal a strong presumption against the government. As elaborated below, however, the narrative of RFRA's enactment and subsequent interpretation maps erratically at best on the uses of these concepts elsewhere in constitutional law.

For lawyers and academics who have tracked the entire mass of contraceptive mandate litigation over the past few years, the many RFRA questions raised in these cases have defied any easy path to resolution. In considerable part, the resistance to clean answers has not simply been the product of the cognitive dissonance produced by the culture wars between conservative religious values and women's reproductive freedom, although that dissonance has surely played a part. For even the most careful and open-minded of lawyers, these cases presented a set of difficult and inter-related questions. Here is a list, inevitably incomplete: ${ }^{10}$

1. Is a corporation a "person" within the meaning of RFRA's operative provision? How can an artificial person exercise religion? Are business corporations a different sort of artificial person than religiously affiliated non-profit entities, such as universities, hospitals, and charities? How can these entities be "persons" if business entities are not?

2. What counts as a "burden" under RFRA, and what makes a burden "substantial"? May courts look at the religious weight and significance (that is, the religious cost of compliance with the law) of the asserted burden, or are they limited to examining the secular costs of noncompliance? Does the employer's choice to drop health coverage and pay a tax make the secular burden of the mandate insubstantial? Does legal pressure that may lead an employer to facilitate the "sins" of others, who make independent behavioral choices, constitute a substantial religious burden on the employer?

\footnotetext{
${ }^{10}$ For an impressively comprehensive identification and analysis of the issues raised in Hobby Lobby, see Martin Lederman, Compendium of Posts on Hobby Lobby and Related Issues, March 17, 2014, available at

http://balkin.blogspot.com/search?q=contraceptive+mandate. For the best appraisal of the Establishment Clause issues at stake in the litigation, see Gedicks \& Van Trammell, note 3, supra; Schwartzman, Tebbe, and Schragger, http://balkin.blogspot.com/2013/11/the-establishment-clause-and.html; http://balkin.blogspot.com/2013/12/hobby-lobby-and-establishment-clause.html; http://balkin.blogspot.com/2013/12/hobby-lobby-and-establishment-clause_9.html.
} 
3. Which interests are compelling enough to justify imposition of such burdens? Are these interests to be measured in gross ("women's health," or "gender equality"), or only as implicated by particular exemption claims (that is, by the marginal cost to the government or affected third parties of recognizing exemptions)? If an employer refuses to cover certain goods in a health insurance policy, is the harm any greater than the cost to employees of self-insuring for those goods? Why should the government be so strenuously interested in avoiding that kind of cost-shifting?

4. When, if ever, is a less restrictive means unavailable to achieve this kind of government interest? In particular, when the interest is in providing some good (contraceptive goods and services, for example) rather than avoiding some privately inflicted harm (an act of violence, for example), can't the government always provide the good itself rather than imposing a duty on private parties to provide that good?

What was striking about the conversation that flowed across these discrete issues was the near total lack of a common frame of reference for discussing them. On every question, advocates talked past each other. When Hobby Lobby's supporters asked why the Green family should be made to leave their religious values at home when they went into business, the government's supporters replied by asking why the Greens should be permitted to impose their religious values on employees and their families. Each side emphasized its own framing, and tended to ignore the opposing frame. ${ }^{11}$

This was not merely an artifact of rhetorical strategy and legal/political positioning. Rather, as Part II below explains, this was a thoroughly predictable feature of the conversation about the content and application of the standards that supposedly guide religious exemptions. The endless plasticity of those standards invites widely disparate lines of argument for advocates, and equally disparate modes of resolution for judges.

\footnotetext{
${ }^{11}$ Professor Tuttle and I played our own parts in this game, though our first joint post on the case to some extent straddled the sides. See Lupu \& Tuttle, http://www.scotusblog.com/2014/02/symposium-religious-questions-andsaving-constructions/ (siding with Hobby Lobby on the question of substantial burden, but arguing that the government should prevail).
} 
As the Contraceptive Mandate Cases made their way through the federal courts, a related cultural conflict exploded. Across the heartland of America, proponents of civil equality for same sex couples dueled legally and politically with religious objectors to that equality. One manifestation of the conflict involved attempts in Kansas, Arizona, Mississippi, and other states to legislate about religious freedom. The proposed Kansas law, entitled "AN ACT concerning religious freedoms with respect to marriage,"12 would have very specifically precluded the imposition of any legal duty on an "individual or religious entity" to provide any services or goods related to any marriage or to the celebration of any marriage, or any legal duty to "treat any marriage ... as valid." ${ }^{13}$ The proposed law defined "religious entity" to include privately held, for profit businesses as well as non-profit entities. ${ }^{14}$

No one had any doubt about the source of political energy that was driving the proposed Kansas law, which passed one House of the state legislature. In the weeks leading up to its consideration, federal district courts in Utah, Virginia, Hawaii, and Oklahoma had ruled that the $14^{\text {th }}$ amendment required the State to allow same-sex couples the same rights to marry as opposite-sex couples. ${ }^{15}$ The proposed Kansas law was an effort to pre-emptively bar the application of antidiscrimination norms, which at the time did not even exist in Kansas law, to businesses, public employees, and others who objected on religious grounds to same sex unions. As such, the proposal triggered a firestorm of criticism, and the state Senate eventually balked and refused to enact the measure. ${ }^{16}$

The bleeding from Kansas quickly spilled over into a controversy about proposed amendments to Arizona's Free Exercise of Religion Act. ${ }^{17}$ Although neither the Act nor the proposed amendments said anything about weddings,

\footnotetext{
12 Kansas House of Representatives, Session of 2014, Bill No. 2453, By Committee on Federal and State Affairs, entitled "AN ACT concerning religious freedoms with respect to marriage," available at http://www.kslegislature.org/li/b2013_14/measures/documents/hb2453_01_0000.pdf.

${ }^{13}$ Id. at Section 1. (c).

${ }^{14}$ Id. at Section 3. (a).

${ }^{15}$ Amsterdam v. Abercrombie, No. 13-00649 SOM-KSC, 2014 WL 689764 (D. Haw. Feb. 19, 2014); Bishop v. United States ex rel. Holder, 962 F. Supp. 2d 1252 (N.D. Okla. 2014); Bostic v. Rainey, 970 F. Supp. 2d 456 (E.D. Va. 2014); McGee v. Cole, No. 3:13-24068, 2014 WL 321122 (S.D. W. Va. Jan. 29, 2014); Bourke v. Beshear, No. 3:13-CV-750H, 2014 WL 556729 (W.D. Ky. Feb. 12, 2014); Evans v. Utah, No. 2:14CV55DAK, 2014 WL 2048343 (D. Utah May 19, 2014); Kitchen v. Herbert, 961 F. Supp. 2d 1181 (D. Utah 2013), aff'd 2014 WL 2868044 (No. 13-4178, 10 ${ }^{\text {th }}$ Cir. June 25, 2014).

${ }^{16}$ Wichita Eagle, http://www.kansas.com/2014/02/18/3297322/kansas-senate-kills-controversial.html.

${ }^{17}$ http://www.azleg.gov/legtext/51leg/2r/bills/sb1062p.pdf.
} 
marriages, sex, or gender, the proposal immediately drew fire as an attempt to achieve the same ends as the Kansas proposal. The amendments would have explicitly allowed for-profit business corporations to raise state RFRA claims and defenses, ${ }^{18}$ and would have clarified that such defenses were available in private lawsuits as well as actions brought by the State of Arizona. ${ }^{19}$ Critics of these amendments successfully painted them as being "licenses to discriminate" against those in same sex relationships, and Governor Brewer - under great pressure from business interests and threatened with loss of the Super Bowl in Phoenix in February 2015 - vetoed the bill. ${ }^{20}$

A few weeks before oral argument in the Contraceptive Mandate Cases, and a few weeks after the political explosion over religious freedom legislation proposed in Kansas and Arizona, a less well-noticed conflict played out in the State of Mississippi. The state's Republican leaders introduced and advocated for a Religious Freedom Restoration Act. ${ }^{21}$ The proposed Act made no mention of marriage, same sex or otherwise. Moreover, Mississippi (like many other states) neither recognizes same sex marriage nor prohibits discrimination against LGBT people in the distribution of goods and services. Nevertheless, the political conflict over the measure, which eventually became law in a form weaker than originally proposed, ${ }^{22}$ centered precisely on the question of whether the proposal would license that kind of discrimination, in the context of wedding celebrations or otherwise. ${ }^{23}$

In the skirmishing over the Mississippi RFRA, two groups of legal scholars sent letters to the state's legislative leaders with respect to the law's merits and likely impact. The signatories of the first of those letters included a group that had been advocating for the rights of vendors to refuse on religious grounds to

\footnotetext{
${ }^{18} \mathrm{Id}$. at section 41-1493 (5).

${ }^{19} \mathrm{Id}$. at section 41-1493.01, D.

${ }^{20} \mathrm{http}: / /$ www.azcentral.com/news/politics/articles/20140226arizona-jan-brewer-1062-statement.html.

${ }^{21}$ The bill as introduced is here: http://billstatus.Is.state.ms.us/documents/2014/html/SB/26002699/SB2681IN.htm.

${ }^{22}$ The enacted version is here: http://legiscan.com/MS/text/SB2681/2014.

${ }^{23}$ See, e.g., Emily Pettus, Associated Press, Mississippi Governor Signs Religious Freedom Bill that Could Allow AntiGay Discrimination, available at http://www.Igbtqnation.com/2014/04/miss-governor-signs-religious-freedombill-that-could-allow-anti-gay-discrimination/.
} 
provide goods and services to same sex wedding ceremonies. ${ }^{24}$ This communication, under the letterhead of Professor Douglas Laycock, made absolutely no mention of weddings, or discrimination. After describing the pattern of state RFRAs and the content of Mississippi constitutional law, the letter went on to say that "the standard that [the proposed Mississippi RFRA] creates now applies to the federal government and more than 30 of the states, and was the standard for the entire country from $1963-1990$. In the places where this standard applies, it has not been interpreted in crazy ways that have caused problems for those jurisdictions; if anything, these laws have been enforced too cautiously." 25

The second letter, ${ }^{26}$ to which I was a signatory, read in tone and content as if it were addressed to an entirely different legislative proposal. The letter emphasized the potential reliance on a state RFRA to discriminate against LGBT people and others, and it highlighted the strenuous recent enforcement of federal RFRA, upon which Mississippi RFRA (and that of many other states) is modeled. In particular, the letter emphasized that the terms of RFRA "are tilted heavily in favor of religious freedom claims and against competing civil rights concerns. . . . . Recent decisions by the Supreme Court and the lower federal courts highlight [federal] RFRA's significant weighting in favor of religious interests, and against whatever government interests are on the other side." 27 The letter went on to emphasize the (recent) ease of satisfying the requirement of "substantial burden" on the "exercise of religion;" ${ }^{28}$ because "any sort of fine or legal sanction imposed

\footnotetext{
${ }^{24}$ Many of their communications to legislators on this subject are available here: http://mirrorofjustice.blogs.com/mirrorofjustice/2009/08/memosletters-on-religious-liberty-and-samesexmarriage.html.

${ }^{25}$ Letter from Professor Douglas Laycock et al. to Representative Philip Gunn, Speaker of the Mississippi House of Representatives, Feb. 11, 2014, available at ___ (copy on file with author). The signatories included Professor Richard Garnett, Thomas Berg, and Christopher Lund, all of whom had urged the legislatures of other states to create wedding vendor exceptions to state law duties to serve without discrimination based on sexual orientation. See materials archived at Mirror of Justice blog, note _ supra.

${ }^{26}$ Letter by Religious Liberty Scholars Opposing Mississippi Bill 2681, http://www.thirdway.org/publications/795. The signatories included several scholars, myself included, who had earlier urged the Illinois legislature to defeat a legislative proposal (backed by the Laycock group) that would protect the freedom of vendors to refuse on religious grounds to serve same sex weddings. http://blogs.chicagotribune.com/files/five-law-professors-againstchanging-sb-10.pdf.

${ }^{27}$ Letter by Religious Liberty Scholars Opposing Mississippi Bill 2681, http://www.thirdway.org/publications/795 (emphasis added).

${ }^{28}$ Id., quoting Senate Bill 2681, Section 1. (5) (a).
} 
for conduct that the actor asserts is motivated by his religious faith will be sufficient to show such a burden." 29

Moreover, as the letter argued, "once a showing of substantial burden has been made, the requirement in [the Bill] that the government show that application of a law is 'essential to further a compelling state interest' and the 'least restrictive means' ${ }^{30}$ to do so is likely to be very difficult to satisfy. Federal RFRA imposes a nearly identical standard on the federal government. In the most prominent federal RFRA decision to date ...., the Supreme Court unanimously ruled that the federal government had not sufficiently proven that it had a compelling interest in stopping importation of a hallucinogenic drug (hoasca tea), banned by the federal Controlled Substances Act. ${ }^{31}$. . ."

"Suppose [the proposed Mississippi RFRA] becomes law. If a person raises a RFRA defense to a charge under state or local anti-discrimination law (whether already enacted or enacted after [the RFRA]), that person would likely include as part of his defense that other, non-objecting persons provide the same or similar goods and services. Such a person would assert that the existence of alternative providers renders application of the law not "essential" as to him. ... [I]f state courts follow the model of [recent federal decisions], the state's RFRA might protect exactly that kind of discrimination." 32

Was one of these groups of scholars being deceptive or dishonest in its arguments to the Mississippi legislature? I make no such claim. The scholarproponents of Mississippi RFRA had a complex agenda, which included a general concern for religious freedom; this concern extended to empowering at least some religious objectors to same sex marriage. And, as elaborated in Part II.C., below, these proponents quite accurately asserted that a number of state RFRA's had been weakly enforced. The scholar-opponents had a more focused agenda flagging a RFRA as a potential threat to anti-discrimination laws in general, and as constraint on full marriage equality in particular. And the opponents accurately

\footnotetext{
${ }^{29}$ So will any threat of lost government benefits, "exclusion from government programs," or lost "access to governmental facilities" as a result of religious exercise. Id. quoting Senate Bill 2681, Section 1. (4) (a).

${ }^{30}$ Id., quoting Senate Bill 2681, Section 1. (5) (a)(i) - (ii). Note also Section 1. (4) (b): “'Compelling governmental interest' means a government interest of the highest magnitude that cannot otherwise be achieved without burdening the exercise of religion."

${ }^{31}$ Letter by Religious Liberty Scholars Opposing Mississippi Bill 2681, http://www.thirdway.org/publications/795., citing Gonzales v. O Centro, 546 U.S. 418 (2006).

32 Id.
} 
asserted that federal RFRA had become more potent over the past several years, especially in light of the Contraceptive Mandate Cases. The proponents had no interest in flagging the recent surge in strength of federal RFRA; that development undercut their claim that a state RFRA was likely to do some good with little risk of harm.

What was striking to those who were simultaneously monitoring the Contraceptive Mandate Cases and the Mississippi RFRA fight was the conceptual overlap between the federal RFRA questions in the former and the potential questions that the latter might eventually generate. Can a business corporation be a "person" who exercises religion? Is a requirement to provide (or not discriminate in the provision of) certain goods and services a "substantial burden" on the provider's religious exercise, when the provider objects to use of the goods by others for certain purposes? Does the government have a compelling interest in disallowing all exemptions from such obligations, even if alternative methods of provision of these goods are likely to be available?

In the middle of this political debate in Mississippi, Professor Thomas Berg (one of the proponents of the state RFRA and a contributor to this Symposium) commented in a blog post that the atmosphere for proponents of RFRAs had become "toxic." ${ }^{33}$ Indeed. As Professor Berg well knows, the moment's toxicity was a function of the marriage equality battle. But the problem presented by RFRAs, or any other mechanism for adjudication of religious exemptions under general standards, is not momentary, and is not limited to the context of same sex marriage or anti-discrimination law more generally. The problem is territorial and longstanding - such regimes invite sympathy for the plight of religious objectors, but they also invite indeterminacy, result-orientation, and the exercise of official power over questions that are wisely walled off from state resolution by the Constitution.

\section{A Brief History of Religious Exemption Regimes}

\footnotetext{
${ }^{33} \mathrm{http} / / /$ mirrorofjustice.blogs.com/mirrorofjustice/2014/03/the-scholars-mississippi-letter-rfras-ingeneral-are-now-bad.htmIMirror of Justice (“ . . politically this is an impossibly toxic time to propose a state RFRA.") The time is anti-toxic for those Mississippi businesses whose owners oppose anti-gay discrimination, and are publicizing their opposition to what they believe the state RFRA represents. See "Business Owners Challenge Anti-Gay Law, http://www.washingtonblade.com/2014/07/11/business-owners-challenge-anti-gay-miss-law/. (showing anti-discrimination seal that such business owners are putting on their shop doors.)
} 
Like the subject of time, a narrative history of religious exemption regimes does not invite brevity. ${ }^{34}$ My thesis, however, depends on explication of this history, and the brief version seems best for present purposes.

A. The Law of the Free Exercise Clause. Prior to 1963, the Court had never held that the Free Exercise Clause, standing alone, supports an exemption from general laws. In 1878, the Court held in Reynolds v. United States, ${ }^{35}$ the Mormon polygamy case, that the Clause protects religious belief, but does not exempt religiously motivated action from otherwise valid laws. As the Court put it in Reynolds, "To permit [religious excuse for violation of legal duty] would be to make the professed doctrines of religious belief superior to the law of the land, and, in effect, to permit every citizen to become a law unto himself." ${ }^{36}$

Constitutional law remained steadfastly true to that proposition for the next eighty-five years. Prior to 1963, all of the victories for religious claimants in the Supreme Court involved assertions of rights that protected secular and religious acts alike. Several of these decisions turned on parental rights under the due process clause; ${ }^{37}$ others, most notably the second Flag Salute Case ${ }^{38}$ and Cantwell v. Connecticut, ${ }^{39}$ depended upon the presence of free speech interests. When the Court confronted claims resting on the Free Exercise Clause alone that is, claims for religious exemptions from duties applicable to others -- the claimant invariably lost. ${ }^{40}$

In 1963, the Supreme Court's 1963 decision in Sherbert v. Verner ${ }^{41}$ signaled a significant change in the law of the Free Exercise Clause. Sherbert involved a claim under South Carolina's unemployment compensation statute, by a Saturday Sabbatarian that she had good cause to refuse employment that required Saturday work. Following the Court's then-recent decision in Braunfeld $v$.

\footnotetext{
${ }^{34}$ Cf. Stephen Hawkings, A Brief History of Time (Bantam, $10^{\text {th }}$ anniversary ed., 1998).

3598 U.S. 145 (1878).

36 Id. at 167.

${ }^{37}$ Meyer v. Nebraska, 262 U.S. 390 (1923); Pierce v. Society of Sisters, 268 U.S. 510 (1925).

${ }^{38}$ West Virginia Board of Education v. Barnette, 319 U.S. 624 (1943).

${ }^{39} 310$ U.S. 296 (1940). We trace the story of Barnette and Cantwell in more detail in Lupu \& Tuttle, Secular Government, note 2 supra, at 183-189.

${ }^{40}$ See, e.g., Prince v. Massachusetts, 321 U.S. 158 (1944); Minnersville Sch. Dist. v. Gobitis, 310 U.S. 586 (1940).

${ }^{41} 374$ U.S. 398 (1963).
} 
Brown, ${ }^{42}$ which had rejected a claim for free exercise exemption from Sunday Closing Laws, the decision employed the precise language of "substantial burdens" and "compelling interests" that, thirty years later, became the centerpiece for the statutory embrace of religious freedom.

Sherbert was far more ambiguous than present-day restorers make it appear; the decision turned in part on the discrimination in South Carolina law in favor of Sunday Sabbatarians. ${ }^{43}$ Moreover, Sherbert did not "exempt" the claimant from anything. The Court did not hold that Mrs. Sherbert could refuse work without good cause and still collect unemployment benefits; rather, it ruled that her religious commitments constituted good cause as a matter of the state's constitutional duty to avoid burdening religious freedom. Sherbert is a decision about a constitutionally mandatory extension of benefits, rather than an exemption from general norms.

Wisconsin v. Yoder, ${ }^{44}$ decided in 1972, is the true and only lynchpin of the restoration movement. Yoder held that the Free Exercise Clause exempted adult members of the Old Order Amish from the obligation to send their children to school until the age of 16 . Yoder is indeed an exemption case, and it is expressly limited to religiously motivated claims to such an exemption; ${ }^{45}$ on its own terms, it rests on the Free Exercise Clause, and not on a religion-indifferent doctrine of parental rights. This is precisely what makes Yoder different from the Second Flag Salute Case, ${ }^{46}$ where a religion-indifferent freedom from compelled speech, rather than religious conscience, is doing all the work.

Like Sherbert, Yoder also utilized the language of substantial burden and compelling interests, but a close examination of the opinion reveals it to be an exercise in even-handed balancing of interests, with close attention to the harms at the margin of each side's concerns. The Court carefully analyzed, in light of facts in the record, the beliefs of the Old Order Amish concerning their obligations

\footnotetext{
42366 U.S. 599 (1961). I examine the rise of the compelling interest test in Free Exercise cases, and its connection to seemingly analogous standards in free speech cases, in Ira C. Lupu, Where Rights Begin: The Problem of Burdens on the Free Exercise of Religion, 102 Harv. L. Rev. 933 (1989).

${ }^{43} 374$ U.S. at 406 ((discriminatory treatment of Saturday Sabbatarians in state law compounds the constitutional problem).

44406 U.S. 205 (1972).

${ }^{45}$ Id. at 215-216 (distinguishing claims based on secular philosophy from those based on religious belief). These themes are elaborated further in Lupu \& Tuttle, supra note 2, at 192-195.

${ }^{46}$ West Virginia Board of Education v. Barnette, 319 U.S. 624 (1943).
} 
to maintain the continuity of their religious community, and the likely effects on that community if the Amish are not exempted from the obligation to send their 14-15 year olds to school. ${ }^{47}$ And the Court likewise examined the precise impact of an exemption on the state interests -- having minimally educated, independent, self-reliant citizens -- that Wisconsin claimed were at stake. ${ }^{48}$ Only after a detailed comparison of the effects on both sides of this equation did the Court resolve the case in favor of the Amish.

Between Yoder and Employment Division v. Smith, the path of free exercise decisions in the Supreme Court is an inconvenient embarrassment to "restorers." The only victories for free exercise claimants in the Supreme Court involved explicit discrimination against religion ${ }^{49}$ or denials of unemployment compensation; indeed, two of the three unemployment cases involved Sabbatarians, ${ }^{50}$ similar to Sherbert. The third, Thomas v. Review Board of Indiana, ${ }^{51}$ involved conscientious objection by an employee to involvement in the production of armaments. ${ }^{52}$ Like Sherbert, these subsequent unemployment compensation decisions are also "false exemption" cases. Each of them requires extension of the concept of "good cause" to refuse proffered employment, rather than an exemption from the requirement of good cause. As a "true exemption" case, Yoder is the cheese - it stands alone.

The smattering of unemployment decisions to one side, the decade of the 1980 's demonstrated that the Supreme Court was utterly unprepared to keep the promise that Yoder had apparently made. In case after case, the Court found ways to distinguish Sherbert-Yoder and rule against the free exercise claimant. These rulings fell into three, basic categories. First, the Court held that the

\footnotetext{
${ }^{47} 406$ U.S. at 217-218. That inquiry - the effects of non-exemption on religious concerns - is deeply problematic, because it forces a reviewing court to consider ecclesiastical questions, as well as sociological questions of communal survival over time. The government's courts are constitutionally incompetent to address the ecclesiastical questions, see Hosanna-Tabor Evangelical Lutheran Church \& School v. EEOC, 132 S. Ct. 694 (2012), and institutionally ill-equipped to address the sociological ones. The Yoder opinion revealed little sign of awareness of either of these concerns, but they came home to roost in the years that follow. See Lupu \& Tuttle, note 2 supra, at $43-73 ; 227-232$.

48406 U.S. at 224-225.

${ }^{49}$ McDaniel v. Paty, 435 U.S. 618 (1978) (state may not bar clergy from elected office).

${ }^{50}$ Hobbie v. Unemp. App. Comm'n, 480 U.S. 136 (1987); Frazee v. Illinois Dep't of Emp. Sec., 489 U.S. 829 (1989).

${ }^{51} 450$ U.S. 707 (1981).

${ }^{52}$ Significantly for the Contraceptive Mandate Cases, Thomas appears to solve the dilemma of judicial incompetence to resolve ecclesiastical questions by making the claimant the judge of the religious substantiality of the burden he asserts. See Part III infra.
} 
seemingly strict test of Yoder did not apply in government-controlled enclaves the armed forces ${ }^{53}$ and prisons. ${ }^{54}$ The special needs for discipline in such contexts generically trumped religious liberty concerns.

Second, the Court construed the idea of "substantial burdens" to limit it to a) coercive impositions in the form of punishments for religiously motivated acts, or b) conditions inconsistent with faith commitments on government benefits. As the Court elaborated in Thomas v. Review Board: 55 "Where the state conditions receipt of an important benefit upon conduct proscribed by a religious faith, or where it denies such a benefit because of conduct mandated by religious belief, thereby putting substantial pressure on an adherent to modify his behavior and to violate his beliefs, a burden upon religion exists. While the compulsion may be indirect, the infringement upon free exercise is nonetheless substantial."

However expansive this idea of "substantial pressure on an adherent to modify his behavior and to violate his beliefs" may seem, it nevertheless omits some government activity that has profoundly negative effects on faith practices. In Lyng v. Northwest Indian Cemetery Protective Association, ${ }^{56}$ the Court notoriously held that the government's conduct on the public lands, despite the severe and deleterious effects of that conduct on Native American sacred sites, did not constitute a legally cognizable burden on the free exercise of religion by tribes whose sites had been disturbed. ${ }^{57}$ The ruling in Lyng effectively blocked the use of the Free Exercise Clause as a protector of Native American religious rituals and practices on the public lands.

\footnotetext{
${ }^{53}$ Goldman v. Weinberger, 475 U.S. 503 (1986).

54 O'Lone v. Estate of Shabazz, 482 U.S. 342 (1987).

55450 U.S. 707, 717-718 (1981).

${ }^{56} 485$ U.S. 439 (1988).

${ }^{57}$ Lyng v. Northwest Indian Cemetery Protective Ass'n, 485 U.S. 439 (1988). See also Bowen v. Roy, 476 U.S. 693 (1986). For fuller elaboration of $L y n g$ and the conceptual problem of what constitutes a legally cognizable burden on the free exercise of religion, see Ira C. Lupu, Where Rights Begin: The Problem of Burdens on the Free Exercise of Religion, 102 Harv. L. Rev. 933 (1989). The conceptual problem is the same under RFRA, which codifies the preSmith test for "substantial burden." For an important contribution to analysis of this problem under the Free Exercise Clause, see Nomi Stolzenberg, "He Drew A Circle That Shut Me Out": Assimilation, Indoctrination, and the Paradox of A Liberal Education," 106 Harv. Law Review 581 (1993)(commenting on the $6^{\text {th }}$ Circuit's decision in Mozert v. Hawkins County School District that compulsory exposure to certain books does not burden the free exercise interests of a child or her family).
} 
Third, in particular contexts, the Court retreated from a Yoder-style balancing of precise interests at the margin of each side's concerns - that is, the respective costs of exemption and non-exemption. Instead, it categorically generalized the concept of compelling interest. In cases involving claimed exemption from taxation ${ }^{58}$ and from anti-discrimination norms, ${ }^{59}$ the Court stopped analyzing claims at the margin of state interests and vindicated the government's wholesale interest in refusing to entertain any exemption claims whatsoever.

Beyond the subjects of taxation and civil rights, a crucial dictum in United States $v$. Lee ${ }^{60}$ suggested that commercial actors had to comply with generally applicable regulatory regimes, and could never successfully assert religious exemption claims: ${ }^{61}$

"When followers of a particular sect enter into commercial activity as a matter of choice, the limits they accept on their own conduct as a matter of conscience and faith are not to be superimposed on the statutory schemes which are binding on others in that activity."

Thus, on the eve of Smith, the law of the free exercise clause was defined by the fact-bound interest balancing of Yoder, rather than by the presumption of unconstitutionality ordinarily associated with the "compelling interest" test. And that body of law was deeply qualified by the exceptions and limiting principles the Court had identified as ways of evading the Sherbert-Yoder approach. The enclave exclusion, the constrained doctrine of burdens, and the embrace of certain interests as categorically compelling all played an important part in reinforcing judicial reluctance to hold in favor of religious exemption claimants.

Moreover, other considerations operated to hinder Free Exercise exemption claims in the federal courts. Judges were intuitively hostile to the concept of privileging religious objectors, and found ways to limit and reject their claims. ${ }^{62}$.

\footnotetext{
${ }^{58}$ United States v. Lee, 455 U.S. 252 (1982); Hernandez v. Commissioner, 490 U.S. 680 (1989).

${ }^{59}$ Bob Jones University v. United States, 461 U.S. 574 (1983).

${ }^{60} 455$ U.S. 252 (1982).

${ }^{61} 455$ U.S. at 261. The Lee dictum played a pivotal role in the Contraceptive Mandate Cases.

${ }^{62}$ As Jim Ryan wrote in the period after the decision in Employment Division v. Smith and prior to enactment of RFRA, free exercise claims in the halcyon days of Sherbert-Yoder had a dismal track record in the Courts of Appeals
} 
For example, lower courts systematically found ways to distinguish Yoder when other religious actors sought to remove their children from school. ${ }^{63}$ Beyond the use of fact-specific distinctions in particular contexts, other doctrines operated to further limit exemption claims. These included the rule that the sincerity of free exercise claims is subject to examination by judge or jury, ${ }^{64}$ and the possibility of Establishment Clause limitations on the shifting of religion-driven costs to third parties. ${ }^{65}$

\section{B. Employment Division v. Smith and the Religious Freedom Restoration Act.}

In Employment Division v. Smith, ${ }^{66}$ Justice Scalia's opinion called precise attention to the many ways that the courts had breached the promise of Yoder. The dispute involved denial of unemployment compensation to drug and alcohol counselors who had lost their jobs for "misconduct" - in particular, using peyote in the sacraments of the Native American Church. The Court could have easily disposed of Smith under the weakened compelling interest test, as a "drug case" in which the government's interests were categorically compelling. ${ }^{67}$ But the Court seized upon the case, which (unlike the earlier unemployment compensation decisions) did involve a true claim of exemption from conduct norms, as an opportunity to revise the law. Moreover, Smith did not overrule Sherbert, its progeny in cases involving unemployment benefits, or Yoder. Instead, it re-rationalized them in ways that significantly limited their scope. ${ }^{68}$ Smith transformed Yoder, which had been the exclusive lynchpin of a doctrine of religious exemptions, into a decision about hybrid constitutional rights. ${ }^{69}$

as well as in the Supreme Court. James E. Ryan, Smith and the Religious Freedom Restoration Act: A Iconoclastic Assessment, 78 Va. L. Rev. 1407, 1414, 1417 (1992). See also E.E.O.C. v. Townley Engineering \& Mfg. Co., 859 F. $2 d$ 610 app. (9th Cir. 1988) (Noonan, J., dissenting).

${ }^{63}$ See Johnson v. Charles City Community Bd. of Educ., 368 N.W. 2d 74, 83-84 (Iowa 1985). See generally Ira C. Lupu, Home Education, Religious Liberty and the Separation of Powers, 67 B.U. L. Rev. 971 (1987).

${ }^{64}$ United States v. Ballard, 322 U.S. 78 (1944).

${ }^{65}$ See Sherbert v. Verner, 374 U.S. 398, 414-417 (1963) (Stewart, J., concurring in the result); Thomas v. Review Board, 450 U.S. 707, 720-726 (1981) (Rehnquist, J., dissenting).

${ }^{66} 494$ U.S. 872 (1990).

${ }^{67}$ In Smith, Justice O'Connor took precisely this view. Id. at 903-906 (O'Connor, J., concurring in the result).

${ }^{68}$ The Smith opinion described Cantwell and Yoder as cases involving hybrids of free exercise rights and other constitutional rights, and it characterized Sherbert and its progeny as cases involving individualized discretion under broad standards of "good cause." Id. at 881, 884.

${ }^{69}$ Id. at 881. 
Despite Smith's thick resonance with a decade of decline in the strength of Free Exercise Clause standards, critics vilified the opinion as a sudden and dramatic departure from the controlling law of the Clause. ${ }^{70}$ Armed with that rhetoric of unfair, nasty, and constitutionally dangerous surprise, some of the sponsors of the Religious Freedom Restoration Act claimed that the Free Exercise Clause had long and strenuously protected claims for religious exemptions, and that Smith had shockingly and unjustifiably erased that protection. ${ }^{71}$ After several years of legislative tragi-comedy, dominated by opposition to RFRA (as proposed) by the very anti-abortion groups that have ridden RFRA hard in the Contraceptive Mandate Cases, ${ }^{72}$ both Houses of Congress passed the Act by wide margins, ${ }^{73}$ and President Clinton enthusiastically signed it. ${ }^{74}$

Like many regulatory statutes, RFRA represents a classic delegation problem. It offered legislators and the President a chance to vote for a general good, "religious freedom," while leaving to others (primarily the judiciary, rather than regulatory agencies) the task of interpreting and applying its plastic standards. Almost everyone in the enacting Congress was a fan of religious freedom; not a single one stood up and said that members of the Native American Church had a constitutional right to use peyote in their sacraments.

\footnotetext{
${ }^{70}$ See, e.g., Douglas Laycock, The Remnants of Free Exercise, 1990 Sup. Ct. Rev. 1.

${ }^{71}$ See, e.g., statements of Rep. Steven Solarz (D - NY) and Dean Kelley, National Council of Churches, in Report of Hearing before the Subcommittee on Civil and Constitutional Rights, Committee on Judiciary, $101^{\text {st }}$ Cong., $2^{\text {nd }}$ sess., on H.R. 5377 (Religious Freedom Restoration Act of 1990), available at http://www.house.gov/judicary/2.htm.; Religious Freedom Restoration Act of 1991: Hearing on H.R. 2791 Before the Subcomm. on Civil and Constitutional Rights of the H. Comm. on the Judiciary, $102^{\text {nd }}$ Cong. 152-63 (1993)(statement of Nadine Strossen, President, American Civil Liberties Union). Some commentators had a more refined and sophisticated view of what had been going on. See, e.g., Michael W. McConnell, Religious Freedom at the Crossroads, 59 U. Chi. L. Rev. 115 (1992) (describing the law on the eve of Smith as a Potemkin Village): Religious Freedom Restoration Act of 1991: Hearing on H.R. 2791 Before the Subcomm. on Civil and Constitutional Rights of the H. Comm. on the Judiciary, $102^{\text {nd }}$ Cong. 152-63 (1993) (statement of Edward McGlynn Gaffney, Jr.).

72 The U.S. Conference of Catholic Bishops originally opposed the Act, out of a concern that it might empower women to seek abortions for religion-related reasons if Roe v. Wade were overruled (as many expected was imminent at the time). When the Court reaffirmed the core of Roe in Planned Parenthood v. Casey, and Bill Clinton prevailed in the 1992 elections, thereby guaranteeing the preservation and expansion of a pro-Roe majority, the Conference withdrew its opposition to RFRA. See Douglas Laycock, Free Exercise and the Religious Freedom Restoration Act, 62 Fordham L. Rev. 883, TAN 48-49 (1994).

73 Laycock and Thomas, Interpreting the Religious Freedom Restoration Act, 73 Tex. L. Rev. 209,210 (1994).

74 William Jefferson Clinton, Remarks on Signing the Religious Freedom Restoration Act of 1993, 2 PUB. PAPERS 2000 (Nov. 16, 1993).
} 
One of the most elusive and important meta-questions about the Religious Freedom Restoration Act relates to what it "restored." Some of its proponents asserted that it restored the law of the free exercise clause on the eve of Smith. ${ }^{75}$ But, as described a few paragraphs above, that body of law included 1) the exclusion of government enclaves from the Sherbert-Yoder standards; 2) the tight interpretation of "burdens" to exclude the physical impact of government conduct on worship activities; and 3) the categorical embrace of government interests in uniform application of tax rules, civil rights laws, and (arguably) regulations of the employment relationship in commercial settings, as exemplified in United States v. Lee.

Writing in 1995, soon after RFRA's enactment, I flagged the precise set of questions about the scope and meaning of statutory restoration of judicially created constitutional standards. ${ }^{76}$ In March of 2014, those questions ripened in the Supreme Court. As elaborated further in the discussion in Part III. below of the Contraceptive Mandate Cases, Justice Kagan and Paul Clement, counsel for Hobby Lobby, squared off during oral argument on the scope of what RFRA restored - in particular, whether RFRA codified the Lee dictum about religious actors effectively waiving religious objections when entering the commercial sphere. Justice Kagan suggested that RFRA should be construed as if it incorporated by reference the pre-Smith constitutional law of free exercise, including the Lee dictum. ${ }^{77}$ As one would expect, Clement leaned on the precise formula in RFRA as the relevant law of the statute, and rejected the idea that language used in application of a similar constitutional formula in Lee operated to qualify RFRA's governing norms. ${ }^{78}$ The exchange further highlights the dilemma of RFRA's indeterminacy; it references

\footnotetext{
${ }^{75}$ See, e.g., statements of Rep. Steven Solarz (D - NY) and Dean Kelley, National Council of Churches, in Report of Hearing before the Subcommittee on Civil and Constitutional Rights, Committee on Judiciary, $101^{\text {st }}$ Cong., $2^{\text {nd }}$ sess., on H.R. 5377 (Religious Freedom Restoration Act of 1990), available at http://www.house.gov/judicary/2.htm.

${ }^{76}$ Ira C. Lupu, Of Time and the RFRA: A Lawyer's Guide to the Religious Freedom Restoration Act, 56 Mont. L. Rev. 171 (1995) (inquiring whether RFRA restored the law of Free Exercise as of the time of Yoder (1972) or as of the eve of Employment Division v. Smith in the spring of 1990).

${ }^{77}$ Transcript of oral argument in Sebelius v. Hobby Lobby, http://www.ovez.org/cases/20102019/2013/2013 13 354, at pp. 3-5. Writing in 1995, I flagged the precise question that occupied this moment in oral argument and later drew attention in the Hobby Lobby opinions. For a more general elaboration of the issues raised by enacted law that uses terms from judge-made constitutional law, see Ira C. Lupu, Statutes Revolving in Constitutional Law Orbits, 79 Va. L. Rev. 1, 56-62 (1993).

78 Transcript of oral argument in Sebelius v. Hobby Lobby, http://www.oyez.org/cases/20102019/2013/2013 $13 \quad 354$, at pp. 3-5.
} 
the "standard set forth in Sherbert ... and Yoder,"79 without reference to the ways that the Court had ignored or weakly implemented that standard in many decisions after 1972.

\section{Litigation under Federal RFRA}

To what extent did RFRA codify or depart from the pre-Smith gloss on the Free Exercise Clause? As the law of RFRA developed in the lower federal courts, what emerged over time was the view that RFRA had adopted some but not all of that interpretive baggage. Significantly, the Act did not specifically address the exclusion of government enclaves from the full protection of the Free Exercise Clause, but subsequent interpretations have accepted that RFRA covers prisons ${ }^{80}$ and the armed forces. ${ }^{81}$ The character of those enclaves affects the analysis, because certain government interests are stronger in these contexts, but RFRA standards nevertheless apply. ${ }^{82}$

In contrast to its silence on the status of enclaves, RFRA explicitly adopts the judicially created language of substantial burdens and compelling interests. Prior to the Contraceptive Mandate Cases, the pre-Smith law with respect to those terms became part of RFRA's gloss. In particular, courts in RFRA cases involving public lands repeatedly adopted the "substantial burdens" limitation from Lyng. ${ }^{83}$ With respect to the pre-Smith treatment of certain interests as categorically compelling, courts hearing RFRA-based challenges to federal taxation continue to adhere to a RFRA policy of rejecting exemption claims in the name of tax uniformity. ${ }^{84}$ Prior to the Contraceptive Mandate Cases, however, few if any commercial employers relied on RFRA to seek exemption from business

\footnotetext{
7942 U.S.C. sec. $2000 \mathrm{bb}(\mathrm{b})$ (1).

${ }^{80}$ See, e.g., Jolly v. Coughlin, 76 F. 3d 468 (2d Cir. 1996). After the decision in City of Boerne, RFRA no longer applies to state or local institutions of confinement, though RLUIPA has filled that gap. See TAN xxx-xxx infra. In a close vote, the Senate rejected an amendment that would have excluded prisons from RFRA. 139 Cong. Rec. S14468 (daily ed. Oct. 27, 1993). For earlier discussion of the issue of RFRA in prisons, see S. Rep. No. 111, 103 ${ }^{\text {rd }}$ Cong., $1^{\text {st }}$ sess. 18-38 (1993).

${ }^{81}$ Dep't. of Def. Instr. 1300.17, Accommodation of Religious Practices Within the Military Services (Jan. 22, 2014), http://www.dtic.mil/whs/directives/corres/pdf/130017p.pdf.

82 This coverage is made explicitly in the Report pf the Senate Judiciary Committee on RFRA. See Report 103-111, at pp. 9-12.

${ }^{83}$ See cases cited note __, infra.

${ }^{84}$ See, e.g., Thompson v. Comm'r of Internal Revenue, 140 T.C. 173 (T.C. 2013); Moore-Backman v. United States, No. CV 09-397-TUC-RCC (BPV), 2010 WL 3342173 (D. Ariz. June 28, 2010).
} 
regulation, so the question of RFRA's incorporation of the Lee dictum was rarely (if ever) put to the test.

The RFRA regime can be fruitfully broken into three periods -1 ) enactment until the decision in City of Boerne v. Archbishop Flores ${ }^{85}$ (1993-mid-1997), 2) post-Boerne and pre - O Centro (mid-1997 - early 2006); and 3) post - O Centro (early 2006 to date). In the first period, the Act's potential impact was greatest, because its coverage included all of American law. In the second period, the Act effectively covered only federal law, and the Supreme Court had no occasion to construe it. At the outset of the third period, the Court's opinion in Gonzales v. $O$ Centro Espirita Benficente Uniao do Vegetal ${ }^{86}$ (hereafter "O Centro") implicitly validated RFRA's coverage of federal law and applied RFRA with surprising force. But $O$ Centro, like Yoder a quarter-century earlier, represents an outlier rather than a platform for a sustainable regime of free exercise exemptions. As demonstrated by the survey and analysis that follows, RFRA made startlingly little impact on the American law of religious freedom before the Contraceptive Mandate Cases.

Pre-Boerne. The Act became law in 1993, and it applied to all law in the U.S. - federal, state, and local - until the 1997 decision in City of Boerne v. Flores ${ }^{87}$ held it unconstitutional as applied to state and local law. ${ }^{88}$ Accordingly, the period from 1993 through the City of Boerne decision in 1997 represents the only time period in which all of American law was subject to RFRA. This is significant quantitatively, because application to state and local law invited many more potential RFRA claims than would be the case under federal law alone. The original scope of RFRA's application is even more significant qualitatively, because inclusion of state and local government swept a different set of contexts, some (like public schools) quite religion-sensitive, into RFRA's ambit.

After the Court's decision in City of Boerne, I surveyed ALL of the judicial decisions, federal administrative references, and state attorney general opinions

\footnotetext{
85521 U.S. 507 (1997).

${ }^{86} 546$ U.S. 418 (2006).

${ }^{87}$ City of Boerne v. Archbishop Flores, 521 U.S. 507 (1997).

88 Professor Marci Hamilton, who argued successfully for the City of Boerne, remains convinced that RFRA is unconstitutional with respect to federal law as well. Marci Hamilton, The Religious Freedom Restoration Act is Unconstitutional, Period, 1 U. Penn, J. of Const'I Law 1 (1998); see also Professor Hamilton's Brief for Freedom from Religion Foundation in Burwell v. Hobby Lobby Stores, Inc., No. 13-354, 2014 WL (U.S. June 30, 2014).
} 
that involved the Religious Freedom Restoration Act. I called the resulting article "The Failure of RFRA," 89 because the results showed that the Act had accomplished very little. In particular, RFRA had produced 168 judicial decisions. Ninety-nine of these involved litigation by prisoners. ${ }^{90}$ In those 168 cases, courts (primarily but not exclusively federal courts) granted relief in 24, 15 of which were prison cases. Both in and out of prison, the claims prevailed at a rate of about $15 \%$. As I wrote at the time, "When one recalls ... that RFRA had been trumpeted as the protection of religion against all the religion-neutral, generally applicable rules that would beset it, and that RFRA's terms appeared to widely and stringently protect religious exercise, this record of success seems surprisingly tepid." ${ }^{91}$ Tepid, for sure, but on reflection perhaps no surprise - Professor Ryan had found a similar rate of success for free exercise claims in the federal courts of appeals in the decade leading up to Smith. ${ }^{92}$

In the period immediately after Boerne, no generalized regime of federal law requiring religious exemptions applied to state or local law. In 2000, after an aborted attempt in Congress to enact a new and general protection of religious liberty in the states, ${ }^{93}$ Congress enacted the Religious Land Use and Institutionalized Persons Act ("RLUIPA"). As its title suggests, RLUIPA is focused on two discrete contexts - land use and institutionalized persons - in which proponents persuaded Congress that issues of religious discrimination,

\footnotetext{
89 Ira C. Lupu, The Failure of RFRA, 20 U. Ark. at Little Rock L.J. 575 (1998).

${ }^{90}$ Because persons incarcerated for crime are highly litigious and suffer considerable restrictions on all their freedoms, including religious freedom, it remains the case that the great bulk of religious freedom litigation in the U.S. involves prisoners. See, e.g., Holt v. Hobbs, U.S. Sup. Ct. 13-2827, cert granted March 3, 2014 (certiorari to $8^{\text {th }}$ Circuit re: Arkansas prison prohibition on prisoners wearing beards).

9120 Univ. of Ark. at Little Rock L. Rev., at 592. As the article demonstrated, the most common maneuver for courts to use in ruling for the government was to find that the asserted burden was insubstantial, typically because the relevant religious practice was not compulsory as a matter of faith. Id. at 594-595. Subsequent amendments to RFRA's definitional section have closed the door to this particular move. See 42 U.S.C. sec. 2000cc-5 (7) (A) ("The term "religious exercise" includes any exercise of religion, whether or not compelled by, or central to, a system of religious belief.")

${ }^{92}$ Ryan, note xx supra, at 1416-17.

${ }^{93}$ The proposal, named the Religious Liberty Protection Act, foundered on the shoals of a dispute about whether it would protect religious liberty claims to act inconsistently with anti-discrimination laws. For discussion, see James M. Oleske, Jr., Obamacare, RFRA, and the Perils of Legislative History, 67 Vand. L. Rev. EN BANC 77, 82-87 (2014), available at http://www.vanderbiltlawreview.org/content/articles/2014/03/Oleske Perils-of-LegislativeHistory.pdf. ; Douglas Laycock, Douglas Laycock, Imaginary Contradictions: A Reply to Professor Oleske, 67 Vand. L. Rev. EN BANC 89, 91-94 (2014), available at http://www.vanderbiltlawreview.org/2014/03/imaginarycontradictions-a-reply-to-professor-oleske/laycock_response/.
} 
insensitivity, and oppression were widespread. Over the last fourteen years, RLUIPA has made a significant difference with respect to both contexts. ${ }^{94}$

In state and local institutions of confinement, in particular, RLUIPA filled an important gap and has led to thousands of lawsuits. ${ }^{95}$ Whether or not the pattern of decision in these lawsuits has been more principled or consistent than the general pattern under the Free Exercise Clause or RFRA prior to 1997, I cannot say. The sheer number and variety of prison cases make it nearly impossible to fully assess the integrity of this body of law, though a recent filing in the Supreme Court suggests that the RLUIPA prison cases are riddled with deep inconsistencies. ${ }^{96}$

One distinctive vice of the prisoner cases, however, under RFRA or its successor RLUIPA, is their tendency to invite evaluation, by prison administrators and reviewing courts, of the significance of particular religious practices. As my colleague Robert Tuttle and I have discussed elsewhere, the prison cases have on a number of occasions involved "religious experts" who testify or advise on the relative significance of a religious practice, such as prayer frequency, religious diet, or showering before prayer. ${ }^{97}$ This is unsurprising as a matter of institutional control, but constitutionally disturbing. As an elaborate line of decisions show, the official evaluation of religious meaning or significance is beyond constitutional

\footnotetext{
94 I have not surveyed or appraised RLUIPA land use cases. The Becket Fund website lists important decisions from that context, see http://www.becketfund.org/?s=RLUIPA. My colleague Bob Tuttle has appraised the ways in which the Constitution alone might have done the work of RLUIPA in land use cases, see Robert Tuttle, How Firm a Foundation? Protecting Religious Land Uses After Boerne, 68 George Washington L. Rev. 861 (2000). Professor Hamilton has been an implacable and relentless foe of RFRA, RLUIPA, and all such generic religion-protecting regimes. See Marci Hamilton, God vs. the Gavel: The Perils of Extreme Religious Liberty (Cambridge University Press, 2014); and her website, http://rfraperils.com/. Whatever the merits of her views of RLUIPA, my research suggests that she overstates the case that RFRA has led to extreme religious liberty. A regime of lawlessness can cut both for and against religious liberty.

95 Howard Friedman's excellent Religion Clause blog, http://religionclause.blogspot.com, lists thousands of such cases over the last 15 years or so.

${ }^{96}$ An amicus brief recently filed in the Supreme Court argues that the lower courts' interpretations and applications of RLUIPA in prison cases have been riddled with inconsistency. See Brief for Anti-Defamation League et al. , in Holt v. Hobbs, No, 13-6827, available here: http://www.becketfund.org/wpcontent/uploads/2014/05/13-6827tsacAnti-DefamationLeague.pdf.

97 See Lupu \& Tuttle, note 2 supra, at 229-232; Ira C. Lupu \& Robert W. Tuttle, The Forms and Limits of Religious Accommodation: The Case of RLUIPA, 32 Cardozo L. Rev. 1907, 1931-1935 (2011).
} 


\title{
competence. ${ }^{98}$ So RLUIPA sometimes works, but does so at times by using an unconstitutional means of adjudication.
}

\section{RFRA in the Years After City of Boerne}

\author{
Between the decision in City of Boerne in 1997, and the surprisingly \\ religion-favorable decision in C Centro $^{99}$ in 2006, RFRA remained persistently \\ weak. It applied to federal law only, and one principal controversy that arose was \\ whether RFRA provided a defense in private civil actions, especially those brought \\ under federal anti-discrimination law. ${ }^{100}$ My survey of RFRA decisions (federal \\ prison cases excluded) from 1997 to 2006 was limited to cases in the federal \\ courts of appeals. The record here is simple. RFRA claimants NEVER prevailed. ${ }^{101}$
}

\footnotetext{
${ }^{98}$ This is the best explanation of the ministerial exception, broadly upheld in Hosanna-Tabor Evangelical Lutheran Church \& School v. EEOC, 132 S. Ct. 694 (2012), which rests on constitutional incompetence of the state to decide who is fit for ministry. See Lupu \& Tuttle, Secular Government, note __ supra, at 43-61. In Part III, I discuss this problem of ecclesiastical questions in the context of the Contraceptive Mandate Cases, where the question of attenuation between employer decisions about health insurance coverage and employee decisions about contraception has been litigated as part of the inquiry into whether the mandate "substantially burdens" religion. ${ }^{99} 546$ U.S. 418 (2006).

${ }^{100}$ See Shruti Chaganti, Note, Why the [Federal] Religious Freedom Restoration Act Provides a Defense in Suits by Private Parties, 99 Va. L. Rev. 343 (2013). Even when courts held that RFRA did apply in such actions, however, the Act never generated a good defense to anti-discrimination claims. The ministerial exception did all of the defensive work in these cases.

101 Decisions in favor of the government on the ground that the RFRA claimant had not demonstrated a "substantial burden" include: In re The Grand Jury Empaneling of Special Grand Jury, 171 F. 3d 826 (3d Cir. 1999) (no substantial burden in being compelled to testify against rabbi, who was father to the witnesses); Branch Ministries v. Rossotti, 211 F. 3d 137 (D.C. Cir. 2000) (no substantial burden from restrictions on political campaigning by tax exempt church); Worldwide Church of God v. Philadelphia Church of God, Inc., 227 F. 3d 1110 (9th Cir. 2000) (copyright law imposes no substantial burden on church); Henderson v. Kennedy, 253 F. $3 d 12$ (D.C. Cir. 2001) (obeying same speech restrictions as secular groups imposed no substantial burdens); Gary S. v. Manchester Sch. Dist., 374 F. 3d 15 (1st Cir. 2004) (government's failure to provide to disabled children attending Catholic schools the same benefits as it provided to disabled public school children placed no burden on the plaintiffs' exercise of religion).

Decisions in favor of the government on the ground that the government has a compelling interest in imposing a burden on religious exercise include: Adams v. Comm'r of Internal Revenue, $170 \mathrm{~F}$. 3d 173 (3d Cir. 1999) (compelling interest in uniform tax policy); Browne v. United States, 176 F. 3d 25 (2d Cir. 1999) (same); Sutton v. Providence St. Joseph Medical Ctr., 192 F. 3d 826 (9th Cir. 1999); United States v. Sandia, 188 F. 3d 1215 (10th Cir. 1999) (compelling interest in protecting golden eagles); Gibson v. Babbit, 223 F. 3d 1256 (11th Cir. 2000) (compelling interest in protecting bald and golden eagles); United States v. Indianapolis Baptist Temple, $224 \mathrm{~F} .3 \mathrm{~d}$ 627 (7th Cir. 2000) (compelling interest in uniform application of tax policy); United States v. Oliver, 255 F. $3 d 588$ (8th Cir. 2001) (compelling interest in preserving bald eagle population); Guam v. Guerrero, 290 F. 3d 1210 (9th Cir. 2002) (compelling interest in enforcing Guam's restrictions on importing marijuana); United States v. Hardman, 297 F. 3d 1116 (10th Cir. 2002) (compelling interest in protecting bald eagles); Holy Land Foundation for Relief and Development v. Ashcroft, 333 F. 3d 156 (D.C. Cir. 2003) (compelling interest in blocking gift to designated terrorist organization); United States v. Antoine, 318 F. 3d 919 (9th Cir. 2003) (compelling interest in protecting bald and golden eagles): United States v. Brown, 330 F. 3d 1073 (8th Cir. 2003) (compelling interest in taking blood sample
} 
However one explains this pattern, it indicates a persistent and gaping chasm between RFRA's promise, as reflected in its stringent statutory formula, and RFRA's performance.

Of course, a weak RFRA is not the same as a hopelessly inconsistent pattern of results under RFRA. A RFRA could be construed in a consistently weak way, as has been the case under some state RFRA's. ${ }^{102}$ To the point of the moment at which this essay is being prepared, a RFRA suddenly made strong by an authoritative Supreme Court interpretation might change the prevailing pattern, and produce consistently pro-religious freedom results.

The Court's decision in Gonzales v. O Centro ${ }^{103}$ advanced a surprisingly strong interpretation of RFRA, and suggested the possibility that RFRA's original promise might actually be realized. In $O$ Centro, a unanimous Supreme Court affirmed the grant of a preliminary injunction, blocking enforcement of the federal Controlled Substances Act against a religious group's importation and use in its sacraments of hoasca tea, a hallucinogenic substance made from Brazilian plant material. The government did not dispute that the ban on importation constituted a substantial burden on the religious exercise of members of the group. Nevertheless, the government asserted that it had the requisite compelling interest(s), as required by RFRA, to impose this burden.

First, the government argued that hoasca tea was dangerous to human health and that importation by the group presented a risk of diversion into illicit drug trafficking. The district court put the government to its proof of these assertions. The court concluded that the proof left the matter in equipoise, ${ }^{104}$ and that the government therefore had failed to meet the burden of persuasion imposed by RFRA. That conclusion may seem obvious from the language of RFRA taken alone, but religious liberty lawyers immediately recognized the dramatic potential of this emphasis on RFRA's assignment to the government of the risk of non-persuasion.

for DNA in criminal case); United States v. Israel, 317 F. 3d 768 (7th Cir. 2003) (compelling interest in prohibiting use of marijuana).

${ }^{102}$ See Part II.C., infra.

103546 U.S. 418 (2006).

${ }^{104} \mathrm{Id}$. at 426. 
Second, aside from any demonstrable dangers associated with allowing a RFRA exemption for sacramental use of hoasca tea, the government made a far more sweeping argument about the need for uniformity in administration of the Controlled Substances Act. This line of argument, drawn from earlier cases about taxation, ${ }^{105}$ drew on the pre-Smith move of softening the compelling interest test by making it categorical, rather than asking whether the government had a compelling interest in denying an exemption in the particular case. Drug cases, the government contended, could not be open to religious exemption claims, because of the intrinsic hazards of highly controlled substances, the high risk of insincere claims, and the slippery slope from one narcotic to the next.

This sort of argument had always fared well in the "marijuana church" cases that appear from time to time in the lower federal courts, ${ }^{106}$ but the Supreme Court was surprisingly unimpressed by it. Strenuously asserting that RFRA's text demanded adjudication of the validity of a burden as applied to the particular person, the Court seized on the statutory exemption for peyote use in the sacraments of the Native American Church. An interest cannot be compelling, the Court said, if other statutory exemptions permit "appreciable damage" to the same interest. ${ }^{107}$ Because hoasca tea and peyote present comparable risks, a statutory religious exemption for sacramental use of peyote undercut the argument that uniform treatment of such substances is essential. Because most federal regulatory regimes include a variety of exceptions, at least some of which permit "appreciable damage" to regulatory concerns, the unanimous $O$ Centro opinion appeared to offer a potent weapon to RFRA claimants.

O Centro's double move to strengthen RFRA - rigorous proof demands on the government's arguments that exemptions threaten its compelling interests, and reliance on analogous statutory exceptions as evidence of weakness in those interests - should have led to spill-over effects in the lower courts. But, true to the longstanding experience that judges are presumptively inclined against religious exemptions, the results have been quite to the contrary.

\footnotetext{
105 Hernandez v. Comm'r, 490 U.S. 680 (1989); United States v. Lee, 455 U.S. 252 (1982). See also Goldman v. Weinberger, 475 U.S. 503 (1986) (need for uniformity within the Armed Forces).

${ }^{106}$ There are a significant number of cases in which RFRA has been raised unsuccessfully as a defense to federal prosecutions for use, possession, or trafficking of marijuana. See cases cited in note and note _, infra (post- $O$ Centro).

107546 U.S. at 433. , supra (pre- $O$ Centro),
} 
In an exceptionally sophisticated student Note, ${ }^{108}$ published in 2009, Matthew Nicholson identified a striking tendency in the Courts of Appeals to retain the pre- $O$ Centro status quo. These included a tight limitation on what counts as a substantial burden under RFRA; ${ }^{109}$ continued reliance on pre-Smith free exercise decisions which adopted the categorical approach to compelling interests; ${ }^{110}$ deference to the government's assertion that certain, narrowly framed interests are compelling; ${ }^{111}$ and a weak or deferential application of $O$ Centro's emphasis on statutory exemptions as evidence that government interests are less than compelling. ${ }^{112}$ As the Note demonstrates, $O$ Centro quickly became an outlier rather than a stimulant to a new and tougher reading of RFRA. One might say that $O$ Centro is to RFRA as Yoder was to Free Exercise law - sounds tough, plays weak.

My own inquiry into results in the lower federal courts since publication of that Note has confirmed both the inconsistency thesis and the weakness thesis that runs through this narrative. Of the thirty or so non-prison cases decided on the RFRA merits, claimants prevailed in whole or part in only four. One involved importation of Brazilian Daime tea, a substance very much like the hoasca tea in $O$ Centro, used in the sacraments of the Brazilian Santo Daime religion. ${ }^{113} \mathrm{~A}$ second concerned the prohibition of beard-wearing by firefighters in the District of Columbia; ${ }^{114}$ the evidence did not support the District's concern that facial hair

\footnotetext{
108 Matthew Nicholson, Note, Is O Centro a Sign of Hope for RFRA Claimants?, 95 Va. L. Rev. 1281 (2009). 10995 Va. L. Rev. at 1301-1307, citing Navajo Nation v. U.S. Forest Service, 535 F.3d 1058 (9 ${ }^{\text {th }}$ Cir. 2008) (e banc). In Navajo Nation, the $9^{\text {th }}$ Circuit followed the pre-Smith decision in Lyng v. Northwest Indian Cemetery Protective Ass' $n$ to the effect that government conduct on its own land cannot inflict a legally cognizable burden on Native America worship sites on that land. In the "Failure of RFRA," note xx supra, I noted that narrow construction of the "substantial burden" term in RFRA was the most popular lower court strategy for limiting the statute's force.

11095 Va. L. Rev. at 1307-1311, citing Jenkins v. Commissioner, 483 F. 3d 90 (2d Cir. 2007) (need for uniformity in tax cases survives O Centro); Olsen v. Mukasey, $541 \mathrm{~F}$. 3d 827 ( ${ }^{\text {th }}$ Cir. 2008) (need for uniformity in cases involving RFRA challenges to federal restrictions on use of marijuana).

11195 Va. L. Rev. at 1311-1319, citing Kaemmerling v. Lappin, 553 F.3d 669 (D.C. Cir. 2008) (government has compelling interest in collecting DNA, despite a religious objection, from a person convicted of a non-violent felony).

11295 Va. L. Rev. 1319-1323, citing U.S. v. Adeyemo, 2008 WL 928546 (ND Cal April 4, 2008) (government interest in forbidding importation of leopard skins not fatally undercut by fact of other unregulated harms that threatened the species more); United States v. Friday, 525 F. $3 d 938$ ( $10^{\text {th }}$ Cir. 2008) (government's interest in prohibiting taking of eagles without a permit not fatally undercut by failure to do more to protect eagles against harm from electric power lines).

${ }^{113}$ Church of the Holy Light of the Queen v. Mukasey, 615 F. Supp. 2d 1210 (D. Ore. 2009), vacated and remanded for narrower relief by $443 \mathrm{Fed}$. Appx. 302 ( $9^{\text {th }}$ Cir. 2011).

${ }^{114}$ Potter v. District of Columbia, 558 F.3d 542 (D.C. Cir. 2009).
} 
interrupted the flow of air when the firefighter wore a face mask. A third involved the treatment in bankruptcy of the Archdiocese of Milwaukee, ${ }^{115}$ and a fourth resulted in a remand of a claim that an IRS employee, a Sikh, had a RFRAbased right to wear a ceremonial dagger at work, when existing practices appeared to permit exceptions from weapons restrictions in analogous cases in federal buildings. ${ }^{116}$ These four decisions appear to take $O$ Centro quite seriously.

The much larger number of losses, however, involved the historically common pattern in which the concepts of "substantial burden" and "compelling interest" were implemented in a government-favoring way. In the former category are decisions involving claims that the government's use of public lands renders them less suitable for worship; ${ }^{117}$ that religious speakers are entitled to access, better than that afforded to secular speakers, to public lands for distributing their message; ${ }^{118}$ and that the government motto, "In God We Trust" burdens any individual religious exercise. ${ }^{119}$ The compelling interest cases include the usual stock of unsuccessful RFRA defenses to charges for religiously motivated killing of bald eagles and the possession of eagle feathers, ${ }^{120}$ and to charges related to religiously motivated uses of marijuana. ${ }^{121} \mathrm{~A}$ smattering of other cases, also decided on compelling interest grounds, raised novel and unsuccessful claims - an asserted RFRA right to transfer funds to private groups in Iraq; ${ }^{122}$ and to refuse to stand when a federal court convened and recessed. ${ }^{123}$

Of course, it is impossible to prove in the strong sense that this last run of post-O Centro decisions is internally inconsistent, or that the full body of RFRA

\footnotetext{
115 In re Archdiocese of Milwaukee, 496 B.R. 905 (E.D. Wis. 2013).

${ }^{116}$ Tagore v. U.S., 735 F.3d 324 (5 $5^{\text {th }}$ Cir. 2013) (remanding for further consideration of evidence on RFRA claim).

117 South Fork Band v. U.S. Dep't of the Interior, 643 F. Supp. 2d 1192 (D. Nev. 2009); U.S. v. 2010 WL 2593966 (D ColoJune 23, 2010); Winnemen Wintu Tribe v. U.S. Dep't of the Interior, 725 F. Supp. 2d 1119 (E.D. Ca. 2010).

${ }^{118}$ Boardley v. U.S. Dep't of the Interior, 605 F. Supp. $2 d 8$ (D.D.C. 2009), rev'd on other grounds, 615 F. $3 d 508$ (D.C. Cir. 2010); Mahoney v. Doe, 642 F. 3d 1112 (D.C. Cir. 2011); United States v. Dillard, 884 F. Supp. 2 d 1177 (D. Kan. 2012).

${ }^{119}$ Newdow v. Peterson, 2014 WL 2198552 (2d Cir. May 28, 2014); Newdow v. Lafeure, 598 f.3d 638 (9 ${ }^{\text {th }}$ Cir. 2010). See also Carmichael v. Sebelius, 2013 WL 5755618 (ED Va, 10/23/13) (objection to Social Security number as including the "mark of the beast" does not state a claim of substantial burden).

120 U.S. v. Hardman, 638 F. 3d 1274 (10 ${ }^{\text {th }}$ Cir. 2011) (consolidated with U.S. v. Wilgus); U.S. v. Aguilar, 527 Fed Appx. 808 (10 $0^{\text {th }}$ Cir. 2013).

${ }^{121}$ Gover v. United States, No. 08-5207, 2009 WL 754692 (W.D. Ark. Mar. 19, 2009); United States v. Lafley, 656 F. 3d 936 (9th Cir. 2011); U.S. v. Lepp, 446 Fed. Appx. 44 (9 ${ }^{\text {th }}$ Cir. 2011); U.S. v. Quaintance, 608 F. 3d $717\left(10^{\text {th }}\right.$ Cir. 2010); Multi-Denominational Ministry of Cannabis and Rastafa, Inc. v. Gonzales, 365 Fed. Appx. 817 (9 $9^{\text {th }}$ Cir. 2010). 122 United States v. Islamic American Relief Agency, 2009 WL 4016478 (W.D. Mo. Nov. 18, 2009).

${ }^{123}$ U.S. v. Ali, 2012 WL 4128387 (D. Minn. Sept. 19, 2012).
} 
case law (without regard to Boerne or $O$ Centro as era markers) is internally inconsistent. As with pre-Smith free exercise decisions, cases can always be distinguished on their facts. But it is telling that the two recent victories include one on all fours with O Centro, and only two others, involving the wearing of masks by bearded firefighters and the wearing of ceremonial daggers into federal buildings, that closely followed $O$ Centro by imposing on the government a rigorous burden of proof. For most of the remainder, it was as if $O$ Centro had changed little or nothing in judicial attitude or analysis. As before, the record shows occasional outlier victories, and a stark pattern of defeats.

As we all know, the contraceptive inclusion requirements under the Affordable Care Act have utterly changed the RFRA landscape. In the last few years, the federal courts have decided far more contraceptive mandate cases under RFRA than all other non-prison RFRA cases combined. Despite the long history of defeats for so many other RFRA claims, plaintiffs making such claims in contraceptive mandate cases have fared exceptionally well. Many of these involve for-profit companies like Hobby Lobby and Conestoga Wood Products; before the Supreme Court decided the Contraceptive Mandate Cases in late June, 2014, the Circuits were split, but for-profit firms won far more cases than they lost. ${ }^{124}$ More surprisingly, perhaps, challengers have also been quite successful at the preliminary relief stage in cases involving the Obama Administration's accommodation of religiously affiliated non-profits, which can certify objection to coverage of contraceptives and thereby be excused from mandatory insurance coverage of such goods and services. ${ }^{125}$

The data strongly suggest that both the analytic method and the victory rate in the contraceptive cases deviate sharply from the pattern in religious

\footnotetext{
${ }^{124}$ According to the Becket Fund's well-maintained list of cases involving the contraceptive mandate, courts have resolved 41 cases involving for-profit firms, and the division runs sharply in favor of RFRA claimants - 35 preliminary injunctions granted as compared to only 6 denied.

http://www.becketfund.org/hhsinformationcentral/\#tab1. The most prominent cases, are of course, the two that were the subject of the grant of certiorari - Hobby Lobby and Conestoga Wood Products.

${ }^{125}$ See id. (listing the cases brought by non-profits, and enumerating 24 preliminary injunctions granted, and only 2 denied.) The most well-known cases in this category are Little Sisters of the Poor Home for the Aged v. Sebelius, 134 S. Ct. 1022 (2014) (granting preliminary relief against enforcement of the mandate, as prescribed in the accommodating regulations governing religiously affiliated charities) and University of Notre Dame v. Sebelius, 743 F.3d 547 ( $7^{\text {th }}$ Cir. 2014) (holding that the accommodation for religiously affiliated non-profits does not impose a substantial burden on the University) (Posner, J.); accord, Michigan Catholic Conference v. Burwell, No. 13-6640, 2014 WL 2596753 ( $6^{\text {th }}$ Cir,., June 2014). See also Wheaton College v. Burwell, http://www.supremecourt.gov/opinions/13pdf/13a1284_ap6c.pdf.
} 
exemption cases in prior times. Throughout the contraceptive coverage litigation, many courts have been unusually receptive to claimants at the "substantial burden" stage, and quite hostile to the government at the "compelling interest" stage. This can be explained in a variety of ways, discussed in Part III, but principled consistency over time with pre-Smith free exercise law, or with the patterns of pre-ACA RFRA law (even after $O$ Centro) is not among them. In the forprofit cases, the Lee dictum ${ }^{126}$ concerning ". . f followers of a particular sect enter[ing] into commercial activity..." who cannot "superimpose[] ... the limits they accept on their own conduct as a matter of conscience and faith ... on the statutory schemes which are binding on others in that activity" - a proposition that had effectively deterred RFRA-based exemption claims by commercial actors for the past twenty years ${ }^{127}$-- suddenly lost its potency. ${ }^{128}$

\section{State Constitutions and State RFRA's}

After Smith and City of Boerne, state law of religious liberty increased significantly in importance. By variety and frequency, most religious libertythreatening encounters between citizens and their governments occur at the state and local level. Smith weakened the First Amendment's restrictions on state and local government; federal RFRA attempted to restore those restrictions, but City of Boerne soon thereafter constitutionally precluded application of federal RFRA to the states. With respect to land use and institutionalized persons, RLUIPA filled this gap, but the great bulk of conflicts between religious liberty and state or local law remain the primary province of state and local law.

In Smith's immediate wake, a few state supreme courts construed their state constitutions to fill the gap created by Smith. ${ }^{129}$ The enactment of federal

\footnotetext{
126455 U.S. at 261.

127 In addition to the Lee dictum, the Court's unanimous opinion in Tony \& Susan Alamo Foundation v. Sec'y of Labor, 471 U.S. 290 (1985) (religious Foundation is not substantially burdened by minimum wage requirements of federal Fair Labor Standards Act with respect to its employees working in commercial enterprises) has also discouraged religious exemption claims by commercial employers.

128 Hobby Lobby Stores, Inc. v. Sebelius, 723 F. 3d 1114 (10th Cir. 2013) (en banc), aff'd sub nom., Burwell v. Hobby Lobby Stores, Inc., No. 13-354, 2014 WL 2921709 (U.S. June 30, 2014); Gilardi v. Dept. of Health and Human Services, 733 F. 3d 1208 (D.C. Cir. 2013), vacated, No. 13-567, 2014 WL 2931834 (U.S. July 1, 2014); Tyndale House Publishers, Inc. v. Sebelius, 904 F. Supp. 2d 106 (D.D.C. 2012), appeal dismissed, No. 13-5018, 2013 WL 2395168 (D.C. Cir. May 3, 2013).

129 The earliest and best account of these developments can be found in Angela Carmella, State Constitutional Protection of Religious Exercise: An Emerging Post-Smith Jurisprudence, 1993 BYU L. REV. 275 (1993) (citing decisions by the Supreme Courts of Minnesota and Washington State). recently suggested the possibility that it
} 
RFRA dampened this surge, and nothing since has done much to reawaken it. ${ }^{130}$ The story most relevant to this article's thesis is that of state RFRA's, which tend strongly to be modeled on federal RFRA - that is, they speak in Sherbert-Yoder terms of burdens on individual religious exercise and compelling state interests in imposing such burdens.

Writing in 2010, Professor Christopher Lund canvassed the judicial results to that date of state RFRA's. ${ }^{131}$ At that time, 16 states had RFRA's; 10 of these were enacted in 1998-2000, in the immediate wake of City of Boerne. ${ }^{132}$ Professor Lund had hoped and expected that the strenuous language of state RFRA's, coupled with the surprisingly strong construction and application of federal RFRA in $O$ Centro, would produce a sturdy and growing body of religion-protective state statutory law. He was quite disappointed by his findings in mid-2010. Here is his summary:

"... [F]our states have never decided even a single case under their state RFRA's. Six other states have decided only one or two cases apiece. . . And when state RFRA claims have been brought, they rarely win. In most jurisdictions, plaintiffs have not won a single state RFRA case litigated to judgment. . [S]ome states have seen significant state RFRA litigation and there have been some very important victories. But in many states, state RFRA's seem to exist almost entirely on the books." ${ }^{133}$ Professor Lund's bottom line was that, despite their strenuous language of protection for religious freedom, "[i]n most places, state RFRAs simply have not translated into a dependable source of protection for religious liberty at the state level." ${ }^{134}$

Professor Lund speculated that many lawyers were unaware of their state RFRA's, and he cited complaints in lawsuits where state RFRA's could have been relied upon but were not. ${ }^{135}$ He did not limit his criticism to the lawyering

\footnotetext{
${ }^{130}$ The California Supreme Court has more recently suggested that it will similarly construe the California Constitution in a pre-Smith, religion-protective way. See [case about doctors refusing to provide reproductive services for same sex couple].

${ }^{131}$ Christopher Lund, Religious Liberty after Gonzales [O Centro]: A Look at State RFRA's, 55 South Dakota L. Rev. 466 (2010).

${ }^{132}$ Since then, only Mississippi has been added to that list. For discussion of the recent fight over the proposed Mississippi RFRA in Spring 2014, see Part I supra.

133 Lund, note xx supra, at 467.

${ }^{134} \mathrm{Id}$. at 468.

${ }^{135} \mathrm{Id}$. at 481 , note 92.
} 
process, however. He described a number of decisions in which state courts had dramatically weakened their state's RFRA's by construing them to require little or nothing more than a test of whether the challenged legal norm had a rational basis as applied to anyone - that is, as adding no force beyond the Smithweakened Free Exercise Clause itself. ${ }^{136}$

At first glance, such a construction of a RFRA seems shocking to anyone who understands the flow of the law in this field - how can an enactment explicitly designed to restore the compelling interest test and thereby strengthen religious liberty be construed as entirely superfluous? As this article has demonstrated, however, judges have always found ways to limit regimes of religious exemptions under general standards, whether they were Sherbert-Yoder standards in the Supreme Court's decisions from the 1980's, or federal RFRA standards both before and after City of Boerne. State court judges, as Professor Lund appraised them in 2010, were just following this pattern with a vengeance.

My own inquiry into the decisional law under state RFRAs since Professor Lund wrote shows a superficial appearance of uptick in success under state RFRAs. Of twenty-two state RFRA cases decided on the merits, I found eight that might be characterized as victories, a far better record than in any prior period under state or federal RFRAs. (Perhaps Professor Lund's scholarly efforts had the desired effect.) But the particulars of these decisions cast them in a somewhat narrower light. Six of these eight came from two states. Illinois produced three of them, ${ }^{137}$ all in the context of land use, and two of the three explicitly involved identical claims under federal RLUIPA. ${ }^{138}$ The Illinois statute added nothing of independent force.

An additional three were decided under the Texas RFRA - one of those involved land use, ${ }^{139}$ a second concerned Santerian animal sacrifice, ${ }^{140}$ and a third

\footnotetext{
${ }^{136} \mathrm{Id}$. at 484-489 (citing decisions from Connecticut and Florida).

${ }^{137}$ World Outreach Conference Center v. City of Chicago, 591 F.3d 531 (7th Cir. 2009); Our Savior Evangelical Lutheran Church v. Saville, 922 N.E. 2d 1143 (III. App. Ct. 2009); Irshad Learning Center v. County of DuPage, 937 F. Supp. 2d 910 (N.D. III. 2013).

${ }^{138}$ World Outreach Conference Center v. City of Chicago, 591 F.3d 531 (7th Cir. 2009); Irshad Learning Center v. County of DuPage, 937 F. Supp. 2d 910 (N.D. III. 2013).

${ }^{139}$ Barr v. City of Sinton, 295 S.W. 3d 287 (Tex. 2009).

${ }^{140}$ Merced v. Kasson, 577 F. 3d 578 (5th Cir. 2009). For an insightful discussion of Merced, see James Oleske, Lukumi at Twenty: Legacy of Uncertainty for Religious Liberty and Animal Welfare Laws, 19 Animal L. Rev. 295 (2013). Professor Laycock, who successfully argued the Santerian animal sacrifice case (Church of the Lukumi Babalu Aye, Inc. v. Hialeah, 508 U.S. 520 (1993)) in the U.S. Supreme Court, was involved in Merced as well as in
} 
involved public school grooming standards as applied to a Native America student. ${ }^{141}$ The Texas RFRA has been the most successful in producing a legally strengthened regime of religious freedom, although at least two of the three victories - the land use case, and the hair length case - might easily have come out the same way under RLUIPA and the $14^{\text {th }}$ Amendment, respectively. ${ }^{142}$ So in the six cases from Illinois and Texas, the state RFRA probably made a dispositive difference in two at most.

The fourteen losses in state RFRA cases involve, among other things, a mix of marijuana defenses, ${ }^{143}$ failed attempts to boost rights of religious speech to position of greater force than analogous secular speech, ${ }^{144}$ relationships between adults and children, ${ }^{145}$ and cases involving sexual abuse by clergy. ${ }^{146}$ Most, though not all, are "compelling interest" cases, where the government's interests easily prevailed. These results disclose no great surprises. But the decisions since Professor Lund published in 2010 show that only in Texas have courts vigorously construed the statute. ${ }^{147}$

Barr v. City of Sinton, 295 S.W. 3d 287 (Tex. 2009).

${ }^{141}$ A.A. ex rel. Betenbaugh v. Needville Indep. Sch. Dist., 611 F. 3d 248 (5th Cir. 2010).

142 For an example of a successful pre-RFRA claim that school grooming standards violate the Constitution, see Alabama \& Coushatta Tribes v. Big Sandy Sch. Dist., 817 F. Supp. 1319 (E.D. Texas 1993).

143 State v. Hardesty, 214 P.3d 1004 (Ariz. 2009); State v. White, 152 P. 3d 1217 (Idaho Ct. App. 2011); State v. Cordingley, 302 P. 3d 730 (Idaho Ct. App. 2013).

${ }^{144}$ Reed v. Town of Gilbert, 832 F. Supp. 2d 1070 (D, Ariz. 2009), aff'd 707 F.3d 1057 (9 $9^{\text {th }}$ Cir. 2013) (Arizona religious freedom statute); Brown v. City of Pittsburgh, 586 F. 3d 263 (3d Cir. 2009) (Pennsylvania religious freedom statute); Phelps-Roper v. County of St. Charles, No. 4:10CV02232 AGF, 2013 WL 4458979 (E.D. Mo. Aug. 20, 2013).

145 Peace v. Peace, No. 1 CA-CV 13-0150, 2014 WL 1884868 (Ariz. Ct. App. May 8, 2014); State v. Bent, No. 29,227, 2013 WL 4517161 (N.M. Ct. App. Aug. 26, 2013), cert. denied 321 P. 3d 126 (N.M. 2013) (religious freedom statute is no defense to charges of unlawful sexual contact with minors by leader of spiritual group).

146 Givens v. St. Adalbert Church, 56 Conn. L. Rptr. 585 (Conn. Super. Ct. 2013); Doe No. 2 v. Norwich Roman Catholic Diocesan Corp., 57 Conn. L. Rptr. 342 (Conn. Superior Ct. 2013).

147 The state RFRA case most prominently discussed at the Symposium is one that produced no decision on its RFRA merits. Elaine Photography v. Willock, 284 P. 3d 428 (N.M. Ct. App. 2012), aff'd 309 P. $3 d 53$ (N.M. 2013 ), cert. denied, http://www.scotusblog.com/case-files/cases/elane-photography-llc-v-willock, No. 13-585, April 7. 2014. involved a New Mexico photographer who refused to provide services for the commitment ceremony of a lesbian couple, and was thereafter the target of a discrimination complaint in New Mexico Human Rights Commission. In seeking review of the agency order against her, the photographer raised a defense under the New Mexico Religious Freedom Restoration Act. The New Mexico Supreme the photographer's federal constitutional defenses on the merits, and ruled that the state statute did not apply to litigation between private parties. The question of applicability of RFRA, state and federal, has become judicially and legislatively important over the past several years. See, e.g., Shruti Chaganti, Note, Why the [Federal] Religious Freedom Restoration Act Provides a Defense in Suits by Private Parties, 99 Va. L. Rev. 343 (2013). I do not address the point in this article. 
The Lessons of Religious Exemption Regimes

Looking back over fifty years of religious exemption regimes - the Free Exercise Clause under the purported reign of Sherbert-Yoder, federal RFRA, and state RFRAs - I find myself drawn to some stark conclusions. First, the legal language of these regimes, in particular the demand for compelling interests to justify non-exemption of burdened religious exercise, is very strenuous. Applied with the vigor of these concepts as utilized in the law of free speech and equal protection, one would expect exemption claims to succeed frequently. But the evidence shows that they don't. The Supreme Court made it a steady practice to honor in the breach the free exercise principles nominally stated in SherbertYoder. The lower federal courts have implemented federal RFRA very weakly, even after the prod from $O$ Centro, and the state courts have tended to do likewise with state RFRAs. For fifty years, judges at all levels have looked for ways to avoid privileging religiously motivated behavior over its secular counterparts.

To be sure, under all these regimes, occasional victories appear, even prior to the extraordinary run of victories in the contraceptive mandate cases. The record shows that these earlier victories tended to reflect the kind of hybrid rights claims discussed in Smith, ${ }^{148}$ or - in rare instances - cases in which state interests seem extremely weak and the countervailing religious interests seem unusually strong. ${ }^{149}$ Taken separately, some of these victories appear manifestly just and appropriate. In most of these cases, however, judges seem ever mindful of the slippery slope of religious exemptions. As I wrote in 1989, "'Behind every free exercise claim is a spectral march; grant this one, a voice whispers to each judge, and you will be confronted with an endless chain of exemption demands from religious deviants of every stripe." ${ }^{\prime 150}$ Despite the Court's sneering reference in $O$

\footnotetext{
${ }^{148}$ See, e.g., EEOC v. Catholic University of America, EEOC v. Catholic Univ. of America, 83 F.3d 455 (D.C. Cir. 1996) (hybrid of free exercise and establishment clause supports ministerial exemption from prohibition on sex discrimination in employment); Thomas v. Anchorage Equal Rights Commission, 165 F.3d 692 (9th Cir. 1999) (hybrid of Free Exercise Clause rights and Takings Clause rights), vacated on ripeness grounds on rehearing en banc, 220 F.3d 1134 (2000).

${ }^{149}$ Cases involving attempts under local zoning laws to shut down church-sponsored programs to feed the homeless are perhaps a good example of this. See, e.g., Western Presbyterian Church v. Bd. of Zoning Adjustments, 862 F. Supp. 538 (D.D.C. 1994). Of course, that assessment is mine; others would weigh interests in this and other cases far differently. That's the nub of the problem of religious exemptions.

${ }^{150}$ Ira C. Lupu, Where Rights Begin: The Problem of Burdens on the Free Exercise of Religion, 102 Harv. L. Rev. 933, 947 (1989).
} 
Centro to this apprehension, ${ }^{151}$ its decision produced very little change in judicial behavior prior to the Contraceptive Mandate Cases.

One promising explanation of this pattern in both the Free Exercise Clause decisions between 1963 and 1990, and the RFRA decisions of the past twenty years, is the enormous range of legal norms that may fall prey to religious exemption claims. The overwhelming majority of speech and press claims attach to laws that regulate the content or process of communications. ${ }^{152}$ In contrast, religious exemption claims may sweep in a range of religious beliefs and practices as wide and deep as the human condition itself, and a correspondingly enormous range of government interests. The Supreme Court has seen very few such claims in the past 20 years, but the lower courts see them quite regularly, in cases from within and without institutions of confinement. It is hardly a wonder that judges in those lower courts, backed by the Supreme Court's own retreat in Free Exercise decisions during the 1980 's, proceed with great caution and persistent deference to government, despite RFRA's bold, religion-protective language. Those judges just don't know what is coming next, and they lack the discretionary jurisdiction that enables the Supreme Court to decide these cases only on very rare occasion.

Writing in 1999, Professor Eugene Volokh commended the statutory approach to religious exemptions, as distinguished from the constitutional approach, on the ground that the statutory approach preserved democratic accountability and control by permitting legislative overrides of particular judicial decisions. ${ }^{153}$ As Professor Volokh pointed out, legislatures are not free to similarly override rights-recognizing decisions, like Yoder, that root exemptions in constitutional norms.

\footnotetext{
151 “ . . . the Government's argument for uniformity is different; it rests not so much on the particular statutory program at issue as on slippery-slope concerns that could be invoked in response to any RFRA claim for an exception to a generally applicable law. The Government's argument echoes the classic rejoinder of bureaucrats throughout history: If I make an exception for you, I'll have to make one for everybody, so no exceptions. But RFRA operates by mandating consideration, under the compelling interest test, of exceptions to "rule[s] of general applicability." 546 U.S. at 436.

152 Speech claims designed to create exceptions to norms outside the direct regulation of communications are notoriously unsuccessful. See, e.g., U.S. v. O'Brien, 391 U.S. 367 (1968) (First Amendment is no defense to critic of military conscription who willfully destroyed his Selective Service certificate as a symbolic protest during Vietnam War). For my own, quite personal take on O'Brien, see Ira C. Lupu, Teaching United v. O'Brien: Three Conversations and the wisdom of John Hart Ely, 16 Green Bag 2d 291 (2013).

${ }^{153}$ Eugene Volokh, A Common Law Model for Religious Exemptions, 46 UCLA L. Rev. 1465 (1999).
} 
This view made perfect sense as a matter of academic logic. Let judges make case by case decisions under general statutory norms, in light of the facts and the precedents, and permit legislatures to correct "mistakes." In practice, however, things have not worked out quite this way. The only Congressional overrides in such cases have been of judicial denials of constitutional claims - with respect to the wearing of religious garb while in the armed forces, ${ }^{154}$ and with respect to exemption from FICA contributions by business firms owned by Old Order Amish. ${ }^{155}$ Congress has never overridden a federal RFRA decision, and no one expects that pattern to change in response to the Contraceptive Mandate Cases. ${ }^{156}$

In the states, the results are nearly identical. My research has disclosed no cases in which a state legislature has overridden a state judicial decision in favor of or against a state RFRA claim. ${ }^{157}$ Professor Lund's work, cited above, identified two instances in which state legislatures amended RFRAs to include a new coverage restriction. ${ }^{158}$ One involved permitting Illinois to relocate cemeteries and graves in light of the modernization of Chicago's O'Hare Airport, ${ }^{159}$ and the other involved a Florida statute that, while RFRA litigation on the matter was pending, excluded from the state's RFRA the statutory requirement for a full-face photograph on a driver's license. ${ }^{160}$ It is not hard to spot a post 9/11 anti-Muslim

\footnotetext{
154 Congress responded to the decision in Goldman v. Weinberger, 475 U.S. 503 (1986), which rejected a free exercise claim to wear a yarmulke (skull-cap) by an Orthodox Jewish Captain while on duty in the Air Force, by enacting 10 U.S.C. $\S 774$ (2006), which specifies norms and processes for religious accommodations with respect to requirements of wearing certain apparel in the Armed Forces.

155 Congress responded to the decision in U.S. v. Lee, 455 U.S. 252 (1982), which rejected a free exercise claim by an Old Order Amish employer to be exempted from FICA contributions on behalf of his Old Order Amish employees, by creating a statutory exemption. See 26 U.S.C. sec. 3127 (a)(2), (b)(1).

${ }^{156}$ Senators Reid, Murray, Boxer and others have sponsored legislation to overturn the result in Hobby Lobby, but no one believes it can be enacted in this Congress. See Robert Pear, Democrats Push Bill to Reverse Supreme Court Ruling on Contraception, N.Y. Times, July 8, 2014, http://www.nytimes.com/2014/07/09/us/politics/democrats-draft-bill-to-override-contraception-ruling.html. Enactments designed to take away particular judicial victories for religious freedom raise their own constitutional problems. See Church of the Lukumi Babalu Aye, Inc. v. Hialeah, 508 U.S. 520 (1993)). See generally Ira C. Lupu, The Case Against Legislative Codification of Religious Liberty, 21 Cardozo L. Rev. 565 (1999).

${ }^{157}$ I inquired of Professor Volokh in June, 2014, whether he was aware of any such overrides, and his answer was no. E-mail Volokh to Lupu, on file with author and HJLG.

158 Lund, note _ supra, at 493-496.

${ }^{159} \mathrm{Id}$. at $493-4 \overline{95}$. The Seventh Circuit upheld the provision against constitutional attack in St. John's United Church of Christ v. City of Chicago, 502 F.3d 616 ( $7^{\text {th }}$ Cir. 2007).

${ }^{160}$ Lund, supra note _ supra, at 495-496. The statute, FLA. STAT. ANN. Sec. 322.142 (1) (West 2010), was designed to pre-empt the state RFRA claim in Freeman v. Dept. of Highway Safety and Motor Vehicles, 924 So. $2 \mathrm{~d}$ 48 (Fla. Dist. Ct. App. 2006). I inquired of Professor Lund in June, 2014, whether he was aware of any additional
} 
bias in cases like the one from Florida. ${ }^{161}$ Aside from momentary fits of that kind, the legislative experience of the past two decades is that RFRA-enacting legislatures are content to delegate in general terms, take credit for protecting "religious freedom," and leave all the hard choices to the judiciary. As this Part has demonstrated, the state and federal judiciary has been less than eager to exercise that discretion in favor of religious liberty.

The enduring qualities of religious exemption regimes - constitutional and statutory, federal or state - are weakness, plasticity, erratic and unpredictable bursts of religion-protective energy, and the consequent tendency to produce deep inconsistencies. The Supreme Court's disposition of Hobby Lobby, and the profound disagreements among the Justices on the wide range of questions presented by the case, powerfully reinforces this appraisal.

\section{The Contraceptive Mandate Cases}

As expected, the Court's decision (per Justice Alito) in Burwell v. Hobby Lobby Stores, Inc. ${ }^{162}$ (hereafter "Hobby Lobby") sent shock waves across the legal and political culture. The division among the Justices took the distressingly predictable form of 5-4, with all the Republican appointees on one side and all the Democratic appointees on the other. Justice Anthony Kennedy wrote a brief and vital concurring opinion ${ }^{163}$ that suggests the route forward, discussed below

Recall the operative four questions in Hobby Lobby, and the logical linkage among them. First, is a for-profit corporation a "person" who can "exercise religion" within the meaning of RFRA ${ }^{164}$ If so, does the mandate to include all forms of pregnancy prevention services in health insurance "substantially burden" the firm's religious exercise? (If not, government wins.) If so, is application of that

\footnotetext{
episodes of such legislative restrictions on coverage in response to particular litigation or other events, and his answer was no. E-mail Lund to Lupu, on file with author and HJLG.

${ }^{161}$ See generally Michael Heise \& Gregory Sisk, Muslims and Religious Liberty in the Era of 9/11: Empirical Evidence From the Federal Courts, 98 lowa L. Rev. 231 (2012).

162573 U.S. __ (2014); 2014 U.S. LEXIS 4505 (U.S., No. 13-354, June 30,2014).

163 Id. at

${ }^{164}$ The opinion does not address whether shareholders of a corporation, closely held or otherwise, are burdened within the meaning of RFRA by obligations imposed by the corporation. This article will similarly not address the question.
} 
burden to the firm "in furtherance of a compelling governmental interest"? (If not, government loses.) If so, is the requirement of such coverage in the employer-purchased health coverage "the least restrictive means of furthering that compelling governmental interest"? (If not, government loses. If so, government wins.)

Hobby Lobby prevailed because it won on questions 1 (person), 2 (substantial burden), and 4 (not the least restrictive means). As explained below, however, the disposition of question 3 - compelling interest - proved to be both the most subtle and surprising.

Before sub-dividing analysis along the lines marked out by of each of these four issues, I want to flag two meta-questions that hover over Hobby Lobby, and that I will address within each of the following issue-oriented sections. The first is a broad methodological problem of statutory interpretation, identified crisply at oral argument ${ }^{165}$ and addressed sharply in both the Court opinion and Justice Ginsburg's principal dissent. What, precisely, did Congress restore when it enacted the Religious Freedom Restoration Act? ${ }^{166}$ Legislative history strongly suggested that Congress was reacting to Smith, and not to the long run of decisions, such as Bob Jones University, U.S. v. Lee, and Lyng, that had qualified and weakened the Sherbert-Yoder regime. The government thus argued that RFRA incorporated by reference the pre-Smith free exercise decisions, or at least the decisions that dealt explicitly and directly with the concepts of "substantial burdens" and "compelling interests." In particular, the government had relied heavily on the Lee dictum about acceptance by business entrants of applicable regulatory regimes. Following this line of argument exactly, Justice Ginsburg's dissent argued that RFRA had essentially codified the Lee dictum, and that Hobby Lobby's claims accordingly should fail. ${ }^{167}$

In Justice Alito's view, however, the language of the statute controlled the case. And that language never points back to any particular result, much less any

\footnotetext{
165 See TAN _, supra.

${ }^{166}$ For contemporaneous elaboration of this point, see Martin Lederman, http://balkin.blogspot.com/2014/07/hobby-lobby-part-xviii-one-potentially.html, flagging my 1995 article that identified this as a core question going forward. Ira C. Lupu, Of Time and the RFRA: A Lawyer's Guide to the Religious Freedom Restoration Act, 56 Mont. L. Rev. 171 (1995) (asking whether a statute written in such strenuous terms would eventually break free from its earlier case law moorings).

${ }^{167}$ Burwell v. Hobby Lobby Stores, Inc., 573 U.S. (2014) (Ginsburg, J., dissenting) (slip op. at 31-32).
} 
dictum, in pre-Smith cases. The text of RFRA never says that Sherbert or Yoder (or any other case) was rightly or wrongly decided. RFRA'S formally declared purposes include restoration of a legal standard "as set forth" (NOT as applied) in Sherbert and Yoder. ${ }^{168}$ That language represented a codification of a standard of review, not a set of judicial opinions. As Alito puts it, "nothing in the text of RFRA ... suggested that the statutory phrase 'exercise of religion under the First Amendment' was meant to be tied to this Court's pre-Smith interpretation of that Amendment." 169

What renders this dispute about interpretive methodology unusual is that virtually all of the relevant terms - exercise of religion, substantial burden, compelling interest, and least restrictive means - are not of Congressional creation. The first comes from the Constitution itself, and the Court had glossed it in a variety of ways. The second, third, and fourth come directly from judicial opinions applying the Free Exercise Clause to particular claims. When Congress asserts restorative purposes, and chooses judicial terms of art in the restorative enterprise, is it not reasonable for the Court to treat those terms as importing their pre-existing judicial gloss? ${ }^{170}$ If Congress wanted a new approach, why did it legislate in terms associated with the prior regime?

The second meta-question looming above the Hobby Lobby opinions is the one to which this entire article is addressed - can judges be reasonably consistent over time, and across widely different fact patterns, in applying concepts like substantial burden, compelling interest, and least restrictive alternative? As the analysis below reveals, each side of the Court (majority and principal dissent) may have dealt with each of the four issues in an internally coherent way. There is room for deep doubt, however, as to whether either side's approach is fully consistent with past decisions under RFRA or the Free Exercise Clause, pre-Smith. More troubling by far, the relevant questions are sufficiently vague that any and all answers to them are equally persuasive; that is, they do not cabin judgment in ways consistent with a rule of law.

\footnotetext{
16842 U.S.C. sec. $2000 b b-(b)$.

169 Hobby Lobby, slip op. at 35.

${ }^{170}$ I originally focused on these questions at the time Congress was considering RFRA. Ira C. Lupu, Statutes Revolving in Constitutional Law Orbits, 79 Va. L. Rev. 1, 56-62 (1993).
} 
I think my readers will be guided most fairly through the four sub-sections that follow if they know my own judgments about the Hobby Lobby litigation. As Professor Tuttle and I posted in February of 2014, ${ }^{171}$ the government should have prevailed. But we disagreed with the government's position on corporate religious exercise, and on whether Hobby Lobby's exercise of religion was substantial burdened by the contraceptive mandate. We believed then, and still believe, that the Establishment Clause requires a construction of RFRA that does not permit the imposition of significant harms on third parties - in this case, female employees and female dependents of all employees. Loss of no-cost coverage of pregnancy prevention services, even for an interim period, is such a harm. Speaking for myself, I think that the government satisfied the compelling interest test, and that the alternative means for providing such coverage are inadequate because of a combination of political, administrative, fiscal, and legal uncertainties. But I do not for a minute believe that the prior law compelled that result and no other.

Here is my analytic breakdown of the four main issues:

A. Corporate religious exercise.

The question whether for-profit corporations could be persons that exercise religion received tremendous attention in the Hobby Lobby litigation. Attached to this question was the related one of whether shareholders (who were quite obviously persons) in closely held companies were the relevant, burdened parties. The government had argued consistently that corporations were not persons, and that the shareholder-persons were not obligated to do anything by the ACA, and so were not burdened.

It was inevitable that the ghost of Citizens United v. FEC ${ }^{172}$ would haunt this corporate personhood question. The Tenth Circuit Court of Appeals, sitting en banc in Hobby Lobby, treated Citizens United as a relevant authority. ${ }^{173}$ Not so the Supreme Court majority, which found an easy route to the answer. The federal Dictionary Act, which defines terms for purposes of the U.S. Code "unless the context indicates otherwise," states that the word "person ... includes

\footnotetext{
171 Lupu \& Tuttle, Religious Questions and Saving Constructions, available at http://www.scotusblog.com/2014/02/symposium-religious-questions-and-saving-constructions.

172558 U.S. (2010).

173723 F. 3d 1114, 1133 (10th Cir. 2013) (en banc).
} 
corporations, companies, associations, firms, partnerships, societies ... as well as individuals." 174 Does the context of RFRA, and "religious exercise," indicate otherwise?

The most grievous flaw in the government's argument to exclude for-profit corporations from RFRA's coverage is that the overwhelming majority of religious institutions are held in the corporate form. Individual human beings, who live and die, do not own houses of worship, religious colleges and universities, religious charities, or religiously affiliated health care institutions. These entities are held in perpetuity in corporate form, in the name of faith communities. It could not possibly be disputed that these entities exercised religion, and many of the Court's prior decisions had of course recognized that. ${ }^{175}$

What distinguishes Hobby Lobby Stores, Inc. from such institutions? ${ }^{176}$ First, by definition, Hobby Lobby has a profit motive, and earnings that inure to the benefit of its owners. That motive disqualifies it from non-profit status, which has considerable legal significance, in tax law or otherwise. But the state has no constitutional warrant for excluding profit-makers from the ranks of entities with religious purposes; that is a theological move, not open to the state. Second, Hobby Lobby's primary commercial purpose is selling products to hobbyists. But religious colleges have primary educational purposes, and religious hospitals have primary purposes of healing the sick, and these purposes do not disqualify any entity from the status of persons exercising religion.

The government, perhaps recognizing this weakness in its conceptual argument, fell back on prior law. Never, the government asserted, had the Supreme Court ruled that a business corporation could exercise religion under the First Amendment or RFRA. But the Court had never ruled otherwise, either, even in cases where it might have done so, ${ }^{177}$ and it had adjudicated free exercise claims by individual business entrepreneurs. ${ }^{178}$ So the question was entirely

\footnotetext{
1741 U.S.C. sec. 1.

${ }^{175}$ See Church of the Lukumi Babalu Aye, Inc. v. Hialeah, 508 U.S. 520 (1993); Gonzales v. O Centro, 546 U.S. 418 (2006). The cases about disposition of church property, see, e.g., Jones v. Wolf, 443 U.S. 595 (1979), are different; they rest on the constitutional requirement of judicial abstention from ecclesiastical issues. Lupu \& Tuttle, note 2 supra, at 61-69.

${ }^{176}$ The best overall work on this subject is Mark Rienzi, God and the Profits: Is There Religious Liberty for MoneyMakers, 21 George Mason L. Rev. 59 (2013).

177 Gallagher v. Crown Kosher Supermarket of Mass., Inc. 366 U.S. 61 (1961).

${ }^{178}$ Braunfeld v. Brown, 366 U.S. 599 (1961).
} 
open. Even if RFRA restored pre-Smith law in its entirety, nothing in that body of law firmly foreclosed a judgment that for-profit corporations might exercise religion. ${ }^{179}$

Of the four Hobby Lobby questions, only the issue of corporate religious personhood had an answer strenuously rooted in legal authority, widespread practice, and legal logic. It was no surprise to me, though barely mentioned in the media coverage of the case, that the Court divided 5-2 on this question. Justices Kagan and Breyer did not join the portions of the dissent that concluded that forprofit corporations could not be persons that exercise religion. ${ }^{180}$ They perhaps did not want to undercut Justice Ginsburg's dissent by openly disagreeing about anything, but they seemed to recognize that the question in the case was not whether Hobby Lobby had RFRA rights; rather, the question was what RFRA rights Hobby Lobby had.

\section{B. "Substantially Burden."}

The concept of "substantial burdens" is the trigger for RFRA's seemingly stringent protection. If the claimant cannot make this showing, the tests of compelling interest and least restrictive means do not kick in. As Professor Tuttle and I have emphasized, ${ }^{181}$ the test of substantial burden has two parts, not just one. Here is our formulation in February 2014 in a SCOTUS blog post: ${ }^{182}$

"As Sherbert and Yoder perfectly illustrate, a burden on religion involves conflict between a person's legal interests and her religious practices. What is rarely noticed, however, is that the collision of interests must meet two measures of substantiality, not just one. The conflict must involve, as in Sherbert, the imposition of substantial secular costs on the religiously compliant person. Less

\footnotetext{
179 The fact that Hobby Lobby and Conestoga Wood Products were closely held, family-run businesses made the argument easier, but there is nothing in the logic of the Hobby Lobby majority that restricts religious exercise to such companies. Publicly traded, widely held companies might develop a religious identity, but the impracticality of obtaining internal agreement on the Board of Directors, or among shareholders, as to what that identity is, makes such assertions of corporate religious personhood extremely unlikely.

${ }^{180} 2014$ U.S. LEXIS at __ (Breyer and Kagan, JJ., dissenting) ((agreeing with Justice Ginsburg that Hobby Lobby should lose on the merits, but asserting the non-necessity of deciding the corporate personhood question and therefore not joining that portion of the Ginsburg dissent.)

${ }^{181}$ Lupu \& Tuttle, supra note 2, at 198-199.

182 Lupu \& Tuttle, Religious Questions and Saving Constructions, available at http://www.scotusblog.com/2014/02/symposium-religious-questions-and-saving-constructions. See also, Lupu \& Tuttle, note 2 supra, at 197-199.
} 
well noticed, the conflict also must involve substantial religious costs for those who comply with secular law. "

Unpacking the dual inquiries into substantiality of a burden sheds considerable light on both the Alito opinion and the Ginsburg dissent in Hobby Lobby. With respect to the secular costs of compliance with faith, Alito emphasizes the huge fines that Hobby Lobby would incur if it offered a nonconforming insurance policy to its employees. ${ }^{183}$ On this point, the Ginsburg dissent offers no challenge.

The nub of disagreement between majority and dissent attaches to the other, less frequently noticed half of the inquiry into "substantial burdens" - their religious substantiality. The government had argued, and Justice Ginsburg agreed, $j^{184}$ that the religious objections to contraceptive coverage were legally insubstantial because they were too attenuated - that is, removed from the choice to use the contraceptives in question. The government was compelling the owners of the companies to include coverage of the contested items in an insurance policy, and the employees independently would decide whether or not to use IUD's or emergency contraception. The majority, per Justice Alito, repudiated any analytic effort to measure the distance between the purchase of insurance and the choice of pregnancy prevention service. Justice Alito insisted that courts have no business addressing whether a set of religious convictions - in this case, that purchasing the objected-to coverage constitutes material cooperation with or facilitation of $\sin$ - are reasonable. ${ }^{185}$ Despite Justice Alito's insistence elsewhere that RFRA did not absorb the entirety of the pre-Smith gloss on the Free Exercise Clause, ${ }^{186}$ here he relies heavily on Thomas v. Review Board, ${ }^{187}$ in which the Court had refused to adjudicate an apparent dispute

\footnotetext{
183 Justice Alito acknowledges that Hobby Lobby had a choice to drop health insurance and make, under the Internal Revenue Code, an assessable payment of $\$ 2000$ per year per full-time employee. Slip op. at 32-33. For whatever reason, the government had never asserted that this option made the secular pressure on employers insubstantial. Alito concludes that the question of whether this option renders the burden insubstantial is an empirical one, turning on the operation of labor markets. In any event, the majority asserts that the argument in unpersuasive, because the owners of Hobby Lobby and Conestoga Wood Specialties have religious motivation for offering health insurance to employees. Slip op. at 33-34. They don't want to drop the coverage, and the payment of $\$ 2000$ per employee just adds to the pressure to maintain coverage that includes the objectionable goods.

${ }^{184}$ Hobby Lobby, Ginsburg dissent, slip op. at 21-23.

185 Hobby Lobby, slip op. at 36.

$186 \mathrm{Id}$. at 48 , note 43 (rejecting the Lee dictum as controlling in a RFRA case).

${ }^{187}$ Thomas v. Review Board, 450 U.S. 707 (1981), cited in Hobby Lobby, slip op. at 37. Justice Alito also cites Emp. Div. v. Smith for the same point, see id., without acknowledging that Smith relied on the point as a reason to
} 
between the claimant and another member of his faith with respect to Biblical interpretation and the wrongdoing of producing armaments or their components. ${ }^{188}$

Justice Ginsburg did not argue (perhaps because the government had failed to point out) that Wisconsin v. Yoder, ${ }^{189}$ the lynchpin exemption case and explicit model for RFRA's operative standards, teaches somewhat to the contrary with respect to the judicial role in evaluating the substantiality of religious burdens. The Yoder opinion is thick with recitation of the evidence of impact of compulsory education on adolescents and the consequences for the survival of the Amish community. ${ }^{190}$ To be sure, Yoder did not involve disputed questions of scripture, like Thomas, but neither did Hobby Lobby.

The Congress that enacted RFRA gave no thought to which burdens are substantial, or to the adjudicative methods that courts might use to decide that question. If the relevant inquiry in Hobby Lobby is ecclesiastical, pertaining to matters of faith alone and resolvable only by intra-faith exegesis and controversy, perhaps Alito is right. If, on the other hand, the relevant inquiry involves the degree of involvement of an insurance policy purchaser in the conduct of the insured employees, the question begins to look more like one of accomplice liability in criminal law ${ }^{191}$ and less like a matter of Bible study. And if RFRA sets the courts free from pre-Smith law, the issue of inquiry into substantiality is an entirely open question, bound down with no precedential encrustation whatsoever.

It is not my purpose here to resolve the methodological or substantive questions involved in application of the "substantial burden" trigger within RFRA. My point is more simple and direct - all paths were open to the Justices. The majority preferred the Thomas rule of judicial abstention; the dissent preferred active judicial involvement in the question of the religious substantiality of the

\footnotetext{
discontinue religious exemptions, not as a doctrinal move in adjudicating when government must provide such exemptions.

188450 U.S. at 715-716 (courts are constitutionally incompetent arbiters of competing scriptural interpretation).

189406 U.S. 205 (1972).

190 Id. at 216-218.

191 Eugene Volokh, The Religious Freedom Restoration Act and Complicity in Sin, THE VolOKH CONSPIRACY (June 30, 2014), http://www.washingtonpost.com/news/volokh-conspiracy/wp/2014/06/30/the-religious-freedomrestoration-act-and-complicity-in-sin/.
} 
burden. Each took the course he or she wanted, and ignored the others. When all paths are equally open, no one is constrained.

C. Compelling government interest (or, The Dog That Didn't Bark) ${ }^{192}$

The Court, having found RFRA's "substantial burden" requirement satisfied, was then obliged to consider RFRA's "exception" -- the statutory provision that imposes two, independent requirements on the government. The initial requirement is that the government "demonstrate[] that application of the burden to the person (1) is in furtherance of a compelling governmental interest." If the government fails to so demonstrate, the case is over; the government loses, and may not impose the burden on the complaining person. No inquiry into "least restrictive means" is necessary in such a case.

The government had argued that a variety of very strong policy arguments supported the mandate of no-cost coverage of contraceptives of all kinds. These included women's reproductive health, gender equality in health costs, increased avoidance of unwanted pregnancies, and the need for at least some contraceptive medicines as treatment for other conditions. ${ }^{193}$ And, at the margin - that is, on the question of a compelling interest in applying the burden to each relevant person or firm - the need to provide every woman with the relevant coverage seemed evident. An exemption for Hobby Lobby would have eliminated that coverage for thousands of female employees and female beneficiaries of all employees. Moreover, a prominent amicus brief had asserted that a RFRA exemption for Hobby Lobby would violate the Establishment Clause by imposing the costs of the owners' faith on the women deprived of coverage. ${ }^{194}$

Nevertheless, a number of other circuit courts had earlier concluded that the government had not satisfied the compelling interest test. ${ }^{195}$ These lower courts had repeatedly looked to the Supreme Court's relatively recent and

\footnotetext{
${ }^{192}$ See Arthur Conan Doyle, Silver Blaze (in which Holmes explains "the curious incident of the dog in the nighttime;" the dog's silence at the approach of a person at night revealed that the person was someone familiar to the dog).

${ }^{193}$ Brief for Petitioner at 46-48, Burwell v. Hobby Lobby Stores, Inc., No. 13-354, 2014 WL 2921709 (U.S. June 30, 2014) (No. 13-354), 2014 WL 173486

${ }^{194}$ Brief for Church-State Scholars Frederick Mark Gedicks et al. as Amici Curiae Supporting Petitioners, Burwell v. Hobby Lobby Stores, Inc., No. 13-354, 2014 WL 2921709 (U.S. June 30, 2014) (No. 13-354), 2014 WL 333891.

195 Hobby Lobby Stores, Inc. v. Sebelius, 723 F. 3d 1114 (10th Cir. 2013) (en banc), aff'd sub nom., Burwell v. Hobby Lobby Stores, Inc., No. 13-354, 2014 WL 2921709 (U.S. June 30, 2014); Gilardi v. Dept. of Health and Human Services, 733 F. 3d 1208 (D.C. Cir. 2013), vacated and remanded, No. 13-567, 2014 WL 2931834 (U.S. July 1, 2014).
} 
unanimous decision in Gonzales v. O Centro, and had noticed the Court's treatment there of the exemption for peyote use by Native Americans. Here is what the Court wrote in O Centro: ${ }^{196}$

"the Executive and Congress itself have decreed an exception from the Controlled Substances Act for Native American religious use of peyote. If such use is permitted in the face of the congressional findings . . . for hundreds of thousands of Native Americans practicing their faith, it is difficult to see how those same findings alone can preclude any consideration of a similar exception for the 130 or so American members of the UDV who want to practice theirs."

In other words, the Act's exception for some religious uses of peyote weakened considerably the government's argument that it had a compelling interest in not making exceptions for religious uses of comparable substances. ${ }^{197}$ In the contraceptive mandate litigation, the most relevant exception to the mandate was the exception for "grandfathered plans," which employers had selected pre-ACA and wished to maintain. A number of circuit courts had pounced on this, along with other exceptions to the ACA, and concluded that the government had failed in its compelling interest argument. ${ }^{198}$

With that background in mind, consider the Supreme Court's treatment of the "compelling interest" question. Justice Alito writes that "it is arguable that there are features of ACA that support" ${ }^{199}$ the view that the government's interest is not compelling, and references the grandfathering exception immediately thereafter. ${ }^{200}$ With $O$ Centro the most recent and only Supreme

\footnotetext{
196546 U.S. at 433.

197 The Court in O Centro followed its reference to the peyote exemption with this: "See Church of Lukumi Babalu Aye, Inc. v. Hialeah, 508 U.S. 520, 547 (1993) ("It is established in our strict scrutiny jurisprudence that `a law cannot be regarded as protecting an interest 'of the highest order' ... when it leaves appreciable damage to that supposedly vital interest unprohibited'" (quoting Florida Star v. B. J. F., 491 U.S. 524, 541-542 (1989) (SCALIA, J., concurring in part and concurring in judgment))).

198 Gilardi v. Dep't. of Health and Human Services, 733 F. 3d 1208 (D.C. Cir. 2013), vacated, No. 13-567, 2014 WL 2931834 (U.S. July 1, 2014); Hobby Lobby Stores, Inc. v. Sebelius, 723 F. 3d 1114 (10th Cir. 2013), aff'd sub nom., Burwell v. Hobby Lobby Stores, Inc., No. 13-354, 2014 WL 2921709 (U.S. June 30, 2014); Korte v. Sebelius, 735 F. 3d 654 (7th Cir. 2013).

199 Hobby Lobby, slip op. at 39.

200 Id. at 40. Justice Alito also references the ACA exemption for employers with fewer than 50 full-time employees, but this is inapposite, because any health insurance those employees obtain, either through employment or on exchanges, will include full contraceptive coverage.
} 
Court RFRA precedent, one would have expected the Court in Hobby Lobby to apply the $O$ Centro analysis of under-inclusion at this point.

There are, of course, some good responses to that argument as applied in Hobby Lobby. First, the grandfathering exception to ACA is essentially a transition rule; the peyote exception is permanent. The peyote exception is tethered to a particular faith with many members, so it was very hard to explain why the government could not consider a RFRA exception with respect to a comparable substance, for a very small religious community. And the government was insisting in $O$ Centro on the need for uniformity in application of the Controlled Substance Act, akin to claimed need for uniformity in enforcement of tax law. ${ }^{201}$ The government made no comparable claim in Hobby Lobby; HHS could live with some exceptions, especially if the biggest one declined quickly over time.

Despite all of these important lines of argument about compelling interests and the relevance of $O$ Centro, neither the majority, dissent, or concurrence engages directly with this line of argument from cites $O$ Centro. Instead, having sympathetically introduced the themes of this argument, Justice Alito abruptly announces that the Court: 202

"find[s] it unnecessary to adjudicate this issue. We will assume that the [asserted] interest . . . is compelling ...., and proceed to consider the final prong of the RFRA test ... whether HHS has shown that the contraceptive mandate is "the least restrictive means of furthering that compelling governmental interest."

This is the mystery of Hobby Lobby. The opinion sounds no bark from the $O$ Centro dog of exceptions to coverage as representing a weakness in any argument that an interest is compelling. No Justice directly mentions $O$ Centro in this connection, despite the facts that $O$ Centro was a unanimous opinion, written by Chief Justice Roberts, and joined by Justice Alito in his first full Term on the Court.

Of course, Justice Kennedy's concurring opinion puts the mystery to rest. He asserts unequivocally that "it is important to confirm that a premise of the Court's opinion is its assumption that the [challenged] HHS regulation ... furthers

\footnotetext{
201 If RFRA is cut loose entirely from Lee and free exercise norms, tax cases too should be adjudicated case by case, not categorically.

202 Hobby Lobby, slip op. at 40.
} 
a legitimate and compelling interest in the health of female employees." ${ }^{203}$ What is evident from that confirmation, and the discussion of alternatives that follows, is that the price of Justice Kennedy's fifth vote for the Court's opinion was nonadjudication of - not agreement upon -- the question of compelling interest. Had Justices Alito, Scalia, Thomas, and Chief Justice Roberts followed the lead of the many lower courts that had found the government's interest uncompelling, they would have stopped their analysis at that point; the government would have lost, and the availability of alternatives would have become legally irrelevant. There is every indication from their abstention on the question that such a move would have made their opinion a plurality only, and that Justice Kennedy's separate opinion would then have controlled the outcome of the case. ${ }^{204}$

There is nothing sinister or professionally inappropriate about the sort of compromise that would lead four Justices to assume an answer to a question one they might well have answered differently on their own - in order to hold a majority. In the RFRA context, however, there is something quite troubling about concluding that the government has substantially violated a person's religious freedom, and then refusing to confront the question of whether the government's interest is strong enough to justify the burden. Other cases in the RFRA pipeline, on contraceptive coverage and otherwise, might have been significantly influenced by a four-Justice plurality opinion on the merits of Hobby Lobby's non-trivial argument that exceptions to the mandate left "appreciable damage" to the government's interest unremedied.

For this dog to have remained quiet is thus profoundly significant. But it is more than that. The absence of engagement with a central question in the case is just one more sign that religious exemption cases involve the worst kind of judicial lawmaking, unguided by what has gone before, or by manageable standards for what should come next. The final issue the Court confronts - the issue on which the future of the contraceptive mandate now turns - reveals this sort of ad hoc, all things considered, "no case controls another" form of adjudication for which the field is now justly infamous.

D. "Least Restrictive Alternative"

\footnotetext{
${ }^{203}$ Hobby Lobby, Kennedy concurrence, slip op. at 2.

${ }^{204}$ Marks v. U.S. , 430 U.S. 188 (1977) (in the absence of a majority opinion, the narrowest opinion in support of the result represents the controlling law).
} 
Some of the instant commentary on Hobby Lobby suggested that the disposition of the case, on grounds that the government had alternatives less restrictive of religious liberty than the challenged mandate, had been driven by Justice Kennedy's hope and expectation of an ultimate win-win result. ${ }^{205}$ And win-win is what we may get, if that is the right label for a result in which the government's accommodation of religiously affiliated non-profits is a) extended by the Obama Administration to for-profit firms like Hobby Lobby, and b) upheld in the Supreme Court, perhaps as early as next Term, in which the Court is likely to hear University of Notre Dame v. Burwell. ${ }^{206}$

If the Court upholds application to objecting religious non-profits of this accommodation, under which affected women receive full contraceptive coverage through third party administrators and health insurers outside of the employer policy, women may be inconvenienced but not deprived of coverage. And religious objectors will be spared the obligation to purchase the coverage, though they will not be spared an association through a series of orders and contracts with the fact of coverage. Whether either side sees that as a win is a matter of dispute. In any event, the Court's hotly contested disposition, just three days after the Hobby Lobby decision, of an injunction request from Wheaton College ${ }^{207}$ suggests that such an ultimate outcome remains in considerable doubt. $^{208}$

Before returning to the operative details, I want to put the analysis of a "least restrictive alternative" in Hobby Lobby in a broader constitutional perspective, as well as a broader RFRA perspective. First, the notion of alternative, more constitutionally sensitive means to the same end is widespread in constitutional law. One sees it, for very recent example, in McCullen v. Coakley, ${ }^{209}$ this Term's decision about the thirty-five foot buffer zone outside abortion clinics; five Justices concluded that the constitutional defect in the Massachusetts law was its

\footnotetext{
${ }^{205}$ For this characterization of the Kennedy view, see Martin Lederman, http://balkin.blogspot.com/2014/06/hobby-lobby-part-xvii-upshot-of.html ${ }^{206}$ University of Notre Dame v. Sebelius, 743 F. 3d 547 (7th Cir. 2014), aff'g, No. 3:13-cv-01276-PPS, 2013 WL 6804773 (N.D. Ind. Dec. 20, 2013).

${ }^{207}$ Wheaton College v. Burwell, U.S., No. 13A1284, July 3. 2014, available at http://www.supremecourt.gov/opinions/13pdf/13a1284_ap6c.pdf.

${ }_{208}$ Martin Lederman, http://balkin.blogspot.com/2014/07/what-next-in-wheaton-college-is-it-also.html

209 U.S.. No. 12-1168, http://www.supremecourt.gov/opinions/13pdf/12-1168 6k47.pdf.
} 
overbreadth. ${ }^{210}$ A smaller zone, or (narrower still) a firm police presence aimed at stopping physical obstruction of patients, might adequately protect access to abortion clinics while permitting more speech. And one sees similar moves in the demand for exploration of race-neutral alternatives to race-specific admission policies in universities; ${ }^{211}$ again, the notion is that government may achieve its legitimate ends with means that do less damage to constitutionally protected values.

The Supreme Court has made such moves for a half-century or more. ${ }^{212}$ Notice, however, that trade-offs are always in play when the Court insists on less drastic alternatives or more narrowly tailored means to legitimate ends. A sturdy police presence, designed to prevent obstruction of access to abortion clinics will leave unchecked more speech than a thirty-five foot "no speech" zone around the building, but the cost will be less protection for the patients' peace of mind at a moment of great stress. A "top $10 \%$ "admission plan will, in some states, produce decent racial and ethnic diversity in a student body, but may undercut optimizing the overall quality of an entering class. ${ }^{213}$ The results are never fully win-win; instead, they are redistributive in foreseeable and unforeseeable ways.

Moreover, these doctrines never truly insist that the government use the LEAST restrictive means to its ends. Any coercive means can be replaced by a non-coercive one. Abortion protestors could be offered government benefits in exchange for ending their harassing protests in front of clinics; or, even less "restrictive," public officials could politely ask the protestors to cut it out. At some point along the range of less restrictive policy choices, the means become politically infeasible, useless, or both.

Within RFRA itself, the adoption of the strenuous formula or "least restrictive means" highlights the question (flagged at the Introduction to this Part III) of whether Congress was restoring pre-Smith free exercise norms, or restoring "religious liberty" by legislating new, more aggressive norms. In Sherbert, the Court had insisted that government avoid gratuitous, religion-suppressing

\footnotetext{
210 Id. at 18-29 (slip op.).

211 See, e.g., Grutter v. Bollinger, 539 U.S. 306, 335-337 (2003) (discussion of 10\% plan as a race-neutral alternative to race-specific admissions policies at Univ. of Michigan Law School).

${ }^{212}$ The subject is hardly new. See Note, Less Drastic Means and the First Amendment, 78 Yale L.J. 464 (1969);

Note, The First Amendment Overbreadth Doctrine, 83 Harv. L. Rev. 844 (1970).

${ }^{213}$ See Fisher v. University of Texas, 133 S. Ct. 2411 (2013).
} 
overbreadth - for example, rather than rejecting all religion-based claims to unemployment compensation because some may be fraudulent, the government must inquire on a case-by-case base into the sincerity of each claim. ${ }^{214}$ When the Court began to weaken the force of the Sherbert-Yoder doctrine in the 1980's, however, it backed away from deploying such a requirement of narrow tailoring, or case-by-case adjudication, across the board. This retreat was most prominent in U.S. v. Lee, ${ }^{215}$ where the Court cited the concept of means "essential to accomplish an overriding governmental interest," ${ }^{216}$ while steadfastly refusing to insist that the government deploy such means in the case of Old Order Amish seeking exemption from FICA contributions for their Amish employees. ${ }^{217}$

In Hobby Lobby, Justices Alito and Ginsburg duel on the connection between the scope of the "least restrictive means" provision and the larger question of what RFRA restores. Relying on the statutory language, Alito asserts that RFRA goes beyond the prior free exercise law; ${ }^{218}$ relying on legislative history, Ginsburg insists that RFRA incorporates the pre-Smith gloss, and goes no further. ${ }^{219}$ In Ginsburg's view, the "least restrictive means" must be "equally effective means" 220 in order to qualify under the statute, and, in the context of the contraceptive mandate, no alternatives are likely to be equally effective.

On the availability of workable alternatives, however, Justice Alito has the votes of all the Justices who joined his majority opinion. His opinion asserts that "[t]he most straightforward way of [providing an alternative less restrictive of religious liberty] would be for the Government to assume the cost of providing the four contraceptives at issue to any women who are unable to obtain them under their health-insurance policies due to their employers' religious objections." 221

\footnotetext{
${ }^{214}$ Sherbert v. Verner, 374 U.S. 398, 408-09 (1963).

215455 U.S. 252 (1982).

${ }^{216}$ Id. at 257-258. See also Thomas v. Review Board, 450 U.S. 707, 718 (1981) ("The state may justify an inroad on religious liberty by showing that it is the least restrictive means of achieving some compelling state interest.")

${ }^{217}$ Congress eventually created just such an exemption, 26 U.S.C. sec. 3127(a)(2), (b)(1), referenced in Hobby Lobby, Ginsburg dissent, slip op. at 32, n. 29.

218 Hobby Lobby, slip op. at 47-48, and note 43.

${ }^{219}$ Hobby Lobby, Ginsburg, J., dissenting, slip op. at 31-35.

${ }^{220}$ Id. at 27.

${ }^{221}$ Hobby Lobby, slip op. at 41.
} 
It is unlikely in the extreme that Congress will appropriate funds to pay for the contraceptives to which Hobby Lobby and other firms (some of which object to all contraceptive methods) object on religious grounds, so this alternative may somehow be theoretically adequate but politically impossible. ${ }^{222}$ If such options count in the calculus of "least restrictive means," the government will never prevail when a person is "substantially burdened" by a program that involves provision of goods, rather than the elimination of harms. The provision of goods - vaccinations, minimum wages, and the entire stock of benefit-creating policies can always be accomplished by direct government expenditure rather than forced regulatory transfers among private parties.

Aside from the alternative of direct provision, the contraceptive mandate deck includes a crucial wild card as another potential alternative. Justice Alito's opinion reminds us that "HHS itself has demonstrated that it has at its disposal an approach that is less restrictive than requiring employers to fund contraceptive methods that violate their religious beliefs. ... HHS has already established an accommodation for nonprofit organizations with religious objections." 223

Does RFRA protect religious objectors against application of that accommodation? The Court opinion is fully noncommittal: ${ }^{224}$

"We do not decide today whether an approach of this type complies with RFRA for purposes of all religious claims. At a minimum, however, it does not impinge on the plaintiffs' religious belief that providing insurance coverage for the contraceptives at issue here violates their religion, and it serves HHS's stated interests equally well."

Justice Kennedy's concurring opinion seems even more emphatic in its conclusion that the government may not mandate direct insurance coverage of these contraceptives when it has already made an accommodation, for religious non-profits, that provides the relevant pregnancy prevention services while

\footnotetext{
222 The opinion goes on to make the highly controversial suggestion that RFRA itself may authorize the Executive Branch to spend money as a way of financing this alternative. Hobby Lobby, slip op. at 41-43. This is an entirely novel, and I think wholly unsupportable, suggestion. RFRA is not an authorizing statute. Its basic rule protects persons against certain religious burdens, and it blocks exceptions to that rule in cases where alternative ways of achieving government ends exist. But RFRA does nothing to authorize, much less require, the government to act in those alternative ways. When alternatives involve affirmative authorization of expenditures and appropriations of money, the Executive Branch must depend on Congress.

${ }^{223}$ Hobby Lobby, slip op. at 43.

${ }^{224} \mathrm{Id}$. at 44 (notes omitted).
} 
impinging less on the objectors' religious beliefs. ${ }^{225}$ He seems skeptical, however, that direct government provision of contraceptive coverage should be considered as an available, less restrictive alternative, when the existing accommodation for non-profits can be extended and satisfy all. ${ }^{226}$

So, as orchestra leader Ted Lewis used to ask his audience, "Is everybody happy?" 227 No. Not a single Justice of the five in the majority has committed to the legality of this accommodation under RFRA. The Alito opinion's emphasis on a direct government payment program suggests that at least four of those who joined it have substantial doubts with respect to the validity of the accommodation as applied to non-profits. Justice Kennedy's opinion, and the clever swerve around the compelling interest question that he effectively forced, suggests that he believes the accommodation is valid under RFRA as applied to for-profits, though he may well have doubts about its validity when applied to non-profits. The outcome of any litigation concerning the accommodation of non-profits thus remains uncertain, and will continue to be for at least another year.

Moreover, there is no guarantee that the Obama Administration will be able to extend the accommodation to for-profits. For HHS to do so will require an extended notice and comment period for a new regulatory obligation, and many third-party administrators, health insurers, and for-profit firms like Hobby Lobby will push back hard against the effort.

Indeed, Hobby Lobby and others are highly likely to litigate under RFRA against such an accommodation if it is ultimately provided. They are likely to assert that they are substantially burdened by any arrangement that makes them cooperate - even by formally announcing their objection to their third party

\footnotetext{
${ }^{225}$ Hobby Lobby, Kennedy concurring, slip op. at 3-4.

${ }^{226}$ Id. at 4: "The parties who were the plaintiffs in the District Courts argue that the Government could pay for the methods that are found objectionable. ... In discussing this alternative, the Court does not address whether the proper response to a legitimate claim for freedom in the health care arena is for the Government to create an additional program.... The Court properly does not resolve whether one freedom should be protected by creating incentives for additional government constraints. In these cases, it is the Court's understanding that an accommodation may be made to the employers without imposition of a whole new program or burden on the Government. As the Court makes clear, this is not a case where it can be established that it is difficult to accommodate the government's interest, and in fact the mechanism for doing so is already in place." (citations omitted.)

227 http://en.wikipedia.org/wiki/Ted_Lewis_(musician)
} 
insurance administrator -- in the provision of coverage. They may even argue more broadly that they are substantially burdened when the government makes their employment of someone a but-for cause of contraceptive coverage to which they object. Accordingly, they may assert that the still less restrictive alternative of a direct government program is fatal to any program that implicates an employer more directly. Whether there will be five votes for or against that position, at the time it may be advanced in the Supreme Court, is impossible to predict. So assuming a win-win outcome, based on an accommodation that has not yet been offered and remains questionable under RFRA, seems more like a leap of faith than a reasoned prediction.

More dubious, however, is the entire enterprise of religious exemptions, of which Hobby Lobby is but a sub-part. Look at where we have ended up. Four Justices may well be ready to insist that direct government provision is the only lawful way to provide contraceptive coverage with respect to objecting employers (or objecting universities, with respect to students). Four others were ready to rule in favor of the contraceptive mandate as applied to Hobby Lobby. One - only one - effectively held out for adjudication of the validity of alternatives.

More generally, not a single Justice has an approach to RFRA, and an accompanying methodology of interpretation, that will square its history with its text, or produce a consistent practice of drawing on pre-Smith decisions as a guide to interpretation of RFRA. Alito and others in the majority like Thomas; Ginsburg and other dissenters are drawn to Lee. Lower courts adjudicating RFRA cases in the future can be forgiven for being completely unsure of where to go from here.

\section{Religious Exemptions in the Wake of Hobby Lobby}

Parts I-II of the paper have argued that regimes of religious exemptions will be rhetorically strong, experientially weak, and hopelessly erratic. Seen against the backdrop painted in Part III, Hobby Lobby portends a RFRA regime that some expect to be fresh and vigorous, but will turn out to be neither.

The Court itself seemed mindful to limit the scope of its ruling. The opinion suggests that other health insurance coverage will not so easily be escaped under RFRA. As Justice Alito wrote, any religious objection to coverage of vaccinations, blood transfusions, or other treatments must be analyzed with respect to its 
particular impact. ${ }^{228}$ If the covered procedure involves life and death, or serious contagious disease, the government's interest in full and immediate coverage will inevitably trump any religious objections. ${ }^{229}$

Business firms may have financial incentives to raise RFRA objections to other regulation of the employment relationship, including wage and hour rules, ${ }^{230}$ the Family and Medical Leave Act, ${ }^{231}$ or the Americans with Disabilities Act. ${ }^{232}$ But the presence of such financial incentives will be a powerful danger signal that religious insincerity lurks behind such claims. Courts should demand evidence of corporate religious sincerity in full proportion to the financial gain a RFRA victory would yield. The contraceptive mandate involves a perfect storm of strong religious convictions, the possibility of working out alternative arrangements, and no apparent financial incentive for firms to raise insincere claims. This combination of circumstances is not likely to recur, and, if the past is any guide to the future, imperfect storms are highly likely to lead to government victories in RFRA cases, especially when the religious objectors are commercial actors. The Court has inflicted no more than a flesh wound to the Lee dictum that commercial actors may not use their religious convictions to evade regulation.

What about civil rights cases, especially those that involve employer objections to paying family benefits to employees with same sex spouses? This is the next wave of RFRA possibilities, ${ }^{233}$ and there is good reason to be concerned about it. In Hobby Lobby, Justice Ginsburg's dissent asked pointedly whether RFRA would require exemptions in cases where commercial businesses asserted religious reasons to discriminate based on race, religion, sex, or sexual orientation. ${ }^{234}$

\footnotetext{
${ }^{228}$ Hobby Lobby, slip. op. at 45-46.

${ }^{229}$ There have been no RFRA or free exercise claims to such coverage under the ACA. One primary reason for this may be that those who object to such procedures do so only with respect to themselves and their family members, and do not object to the coverage of others who consent to such treatment.

${ }^{230}$ In Tony \& Susan Alamo Foundation v. Sec'y of Labor, 471 U.S. 290 (1985), a unanimous Court rejected a free exercise clause objection to application of the wage, overtime, and recordkeeping requirements of the Fair Labor Standards Act, 29 U.S.C. sec. 201 et seq.

${ }^{231} 29$ U.S.C. sec. 2601 et seq.

23242 U.S.C. sec. 12101 et seq.

${ }^{233}$ Professor Tuttle and I flagged this immediately after the decision. Ira Lupu and Robert Tuttle, Hobby Lobby in the Long Run, http://berkleycenter.georgetown.edu/rfp/blog/hobby-lobby-in-the-long-run. See also Ira C. Lupu, Hobby Lobby Endangers Same Sex Benefits, http://www.nationallawjournal.com/id=1202661872503?

${ }^{234}$ Hobby Lobby, Ginsburg dissent, slip op. at 32-33.
} 
Justice Alito's direct rejoinder mentioned race and race alone. ${ }^{235}$ That response conspicuously left open the possibility that he and others who joined him might hospitably entertain RFRA objections when other grounds of discrimination are involved.

This line of concern would be serious indeed if Hobby Lobby is the full invigoration of RFRA that it appears to be. If the past is prologue, however, the lower federal courts are not likely to take much of this bait. I think it unimaginable that a RFRA claim by a commercial business to be free to discriminate in employment based on religion or sex, in violation of Title VII, would be taken seriously. The government has very strong interests in prohibiting such discrimination, and absolutely no "less restrictive means" are available to deal with the resulting harms.

What about discrimination based on sexual orientation? This context is highly likely to present the next cutting edge of RFRA claims. The question could come up immediately under the Family and Medical Leave Act, if an employer objects on religious grounds to an employee who seeks leave to care for a same-sex spouse. More sweepingly, if and when Congress enacts a version of the proposed Employment Non-Discrimination Act ("ENDA"), ${ }^{236}$ some employers may refuse on religious grounds to hire someone who is openly LGBT or, perhaps more likely, refuse to provide any family benefits with respect to a same sex spouse. Will RFRA, or any other legal authority, provide such an employer with a legally sufficient defense?

Soon after the Supreme Court's Hobby Lobby decision, a major part of the LGBT rights coalition withdrew its support for any broad exemption, from the currently proposed ENDA, ${ }^{237}$ for religious non-profit entities. ${ }^{238}$ One reason the

\footnotetext{
235 Hobby Lobby, slip op. , at p. 46: “The principal dissent raises the possibility that discrimination in hiring, for example on the basis of race, might be cloaked as religious practice to escape legal sanction. See post, at 32-33. Our decision today provides no such shield. The Government has a compelling interest in providing an equal opportunity to participate in the workforce without regard to race, and prohibitions on racial discrimination are precisely tailored to achieve that critical goal."

$236113^{\text {th }}$ Congress, H.R. $1755 ; 113^{\text {th }}$ Congress, S. 815 . For more information, see generally http://www.hrc.org/resources/entry/employment-non-discrimination-act.

${ }^{237} 113^{\text {th }}$ Congress, H.R. 1755, https://beta.congress.gov/bill/113th-congress/house-bill/1755 (includes provision making it inapplicable to religious organizations).

${ }^{238}$ See Chris Geidner, Three Reasons LGBT Groups are Fighting Over a Bill That Isn't Going to Become Law, http://www.buzzfeed.com/chrisgeidner/three-reasons-lgbt-groups-are-fighting-over-a-bill-that-isnt.
} 
withdrawing groups cited was the possibility that Hobby Lobby would encourage RFRA objections to ENDA by for-profit firms, and that those objections might be strengthened if ENDA exempts religious non-profits. ${ }^{239}$ This apprehension is entirely reasonable, even though the government's interest in barring LGBT discrimination in employment is very strong, and less restrictive means to prevent or cure the harms of such discrimination are totally unavailable.

What about the religious non-profits themselves? How would they fare under an ENDA that did not broadly exclude them? Title VII of the 1964 Civil Rights Act (which ENDA would amend) already includes a provision that exempts religious organizations from the prohibition on employment discrimination based on religion. ${ }^{240}$ Religious non-profit entities made subject to ENDA might argue that they were free to discriminate against LGBT people if the employer's faith tradition condemned same sex intimacy as sinful. But Section 702 has never been construed to permit discrimination against a group specifically protected by the Civil Rights Act. ${ }^{241}$ Without an ENDA-specific exception, these employers would have to look elsewhere for a defense.

RFRA and Hobby Lobby is where such employers are most likely to look. Any attempt to rely on RFRA as a defense to an action under a broad ENDA, however, is doomed to fail. To be sure, the non-profit religious objectors are likely to be able to show that they are sincere, and that they are substantially burdened in their religious exercise by such an enactment. But the government's interests in covering such employers would be just as compelling as its interests in covering for-profit employers, and there remains no alternative less restrictive than prohibition to block the harms caused by the discrimination.

What of the more imminent scenario of an Executive Order barring such discrimination by federal contractors? ${ }^{242}$ This would not have the imprimatur of Congress, so perhaps religiously objecting employers, relying on RFRA, would argue that the government's interest is short of compelling. I think that

\footnotetext{
${ }^{239} \mathrm{Id}$.

${ }^{240}$ Title VII, Civil Rights Act of 1964, section 702, 42 U.S.C. sec. 2000e-1. The Supreme Court upheld this provision against Establishment Clause challenge in Corp. of Presiding Bishop v. Amos, 483 U.S. 327 (1987).

${ }^{241}$ See, e.g., Memo. from U.S. Ass't Att'y Gen. (2000), 30-32 and accompanying cites, available at http://balkin.blogspot.com/olc.charitablechoice.pdf.

242 Jonathan Capehart, Obama to Sign Executive Order Protecting LGBT Federal Contractors, Washington Post, June 16, 2014, available at http://www.washingtonpost.com/blogs/post-partisan/wp/2014/06/16/obama-to-signexecutive-order-protecting-lgbt-federal-contractors/.
} 
institution-based argument lacks substance, and should fail. In any event, there is no reason to believe it would have five votes on the current Supreme Court.

Should any such Executive Order include a broad and categorical exemption for religious non-profits? That is now a matter of fierce political debate. A group of faith leaders have called on the President to include such an exemption in the Executive Order. ${ }^{243}$ Other faith leaders and a group of legal scholars, myself included, have urged the President to issue the Order without any such exemption. ${ }^{244}$ In this context, all the arguments above (re: ENDA) about the Section 702 exemption, RFRA claims and defenses, and the risk that for-profits will try to exploit the Hobby Lobby decision to piggy-back on an exemption for religious entities play out exactly the same way. Moreover, with respect to both the Executive Order and ENDA, a RFRA-driven exemption for commercial businesses would protect hard-to-ferret-out bigotry, rather than sincere religious conviction. All of these legal bases for religion-based exemption should fail.

What remains are the possible copy-cat effects of Hobby Lobby on the interpretation of state RFRAs. Might such statutes now be construed to protect religiously motivated discrimination in employment based on sexual orientation, or discrimination by wedding vendors (or merchants in other contexts) against same sex couples? Perhaps. But recall several observations from earlier in this article. State RFRAs have been construed very weakly. ${ }^{245}$ It is obviously possible, as my colleagues and I suggested in our letter to the Mississippi legislature, ${ }^{246}$ that Hobby Lobby will indeed generate imitative interpretations by state courts, particularly on the question of corporate religious personhood. Even if that were

\footnotetext{
${ }^{243}$ Michelle Boorstein, Faith Leaders: Exempt Religious Groups from Order Barring LGBT Bias in Hiring, available at http://www.washingtonpost.com/local/faith-leaders-exempt-religious-groups-from-order-barring-lgbt-bias-inhiring/2014/07/02/d82e68da-01f1-11e4-b8ff-89afd3fad6bd story.html. Their letters are here: http://www.irfalliance.org/wp-content/uploads/2014/06/LGBT-EO-letter-to-President-6-25-2014-w-additionalsignatures.pdf (June 25, 2014); http://www.scribd.com/doc/232327567/Religious-Exemption-Letter-to-PresidentObama (July 1, 2014).

${ }^{244}$ See

https://www.dropbox.com/s/8wzzpbviygds1pv/Faith\%20Letter\%20to\%20President\%20Defending\%20Exec\%200rd er\%202014-07-08\%20FINAL.pdf (letter, dated July 8, 2014, to President Barack Obama from faith leaders, urging no exclusion of religious entities from the proposed order); https://web.law.columbia.edu/sites/default/files/microsites/gender-sexuality/executive order_letter final_0.pdf (letter, dated July 14, 2014, to President Barack Obama from legal scholars, likewise urging no exclusion of religious entities).

${ }^{245}$ See Part II.C., supra, and reliance there on the work of Professor Lund.

${ }^{246}$ See TAN __ supra, in Part I.
} 
to occur, however, the states with RFRAs tend overwhelmingly to be the states that do not forbid discrimination in employment, or in sale of goods or services, based on sexual orientation. ${ }^{247}$ That's not a happy omission, but it does mean, in the short run, that many states lack such civil rights provisions against which their RFRAs might operate.

Same sex marriage is likely to arrive, by virtue of judicial decisions under the fourteenth amendment, ${ }^{248}$ in these states sooner than state or local antidiscrimination law for the LGBT population. But if recent history is a guide, such a development in the constitutional law relating to marriage may be more likely to provoke protective anti-discrimination laws than to provoke RFRA interpretations that license otherwise unlawful discrimination. The public outcry against Arizona's proposed religious freedom amendments in early 2014, and the continuing backlash against Mississippi RFRA, ${ }^{249}$ suggests that elected judges will think twice before interpreting a state RFRA to permit otherwise unlawful LGBT discrimination by commercial actors.

As Archibald Cox wisely wrote many years ago, "once loosed, the idea of Equality is not easily cabined." 250 We are witnesses to that proposition playing out with respect to marriage equality. I make no claim to be nearly so wise as the late Professor Cox. But my detailed appraisal of various systems of religious exemption - federal and state, constitutional and statutory - suggests strongly that religious exemptions are in fact rarely loosed and thereafter quite readily cabined. To accomplish this, the courts may rely on narrowing interpretations of substantial burden, ${ }^{251}$ though that now seems unlikely as a first move. The courts

\footnotetext{
${ }^{247}$ By my count, only three states - Connecticut, Illinois, and New Mexico - have both RFRAs AND antidiscrimination laws that protect LGBT people. The New Mexico overlap helps explain the state law conflict in the Elane Photography case described in note __, supra. I derived this count by comparing the list of state RFRAs, in Lund, note _ supra, 55 S.D. L. Rev. 466, 477, n. 6 and Table I (2010)(listing 16 states with RFRAs) with the list of states that protect LGBT people against various forms of discrimination in Douglas NeJaime, Marriage Inequality: Same Sex Relationships, Religious Exemptions, and the Production of Sexual Orientation Discrimination, 100 Cal. L. Rev. 1169, 1190, n.66 (2012) (listing 21 states and the District of Columbia as having laws prohibiting discrimination against LGBT people). Since these two articles were published, I believe the only change in either list is the addition of the Mississippi RFRA described in Part I, supra.

${ }^{248}$ See decisions cited in $\mathrm{n}$. _, supra.

${ }^{249}$ See note _, supra (describing the quickly spreading merchants' campaign in Mississippi to promote nondiscriminatory treatment of customers).

250 Archibald Cox, The Supreme Court, 1965 Term - Foreword: Constitutional Adjudication and the Promotion of Human Rights, 80 Harv. L. Rev. 91, 91 (1966).

${ }^{251}$ This was a typical confining move in the early days of RFRA, especially in prison cases. See Ira C. Lupu, The Failure of RFRA, 20 U. Ark. at Little Rock L.J. 575, 593-596 (1998).
} 
more likely will be generous to the government in determining what counts as a compelling interest, and in refusing to force a weakening of government policy through emphasis on the availability of less restrictive means. In addition, for Establishment Clause reasons or otherwise, the courts may become increasingly drawn to RFRA interpretations that limit the costs that RFRA claimants can impose on private third parties. Whatever the judicial moves, the dubious enterprise of religious exemptions will, yet again, shrivel rather than prosper. 